\title{
A Rifted Margin Origin for the Crescent Basalts and Related Rocks in the Northern Coast Range Volcanic Province, Washington and British- Columbia
}

Randall Scott Babcock

Western Washington University, randall.babcock@wwu.edu

Russ R. Burmester

Western Washington University, russ.burmester@wwu.edu

David C. Engebretson

Western Washington University, david.engebretson@wwu.edu

A. C. Warnock

K. P. Clark

Follow this and additional works at: https://cedar.wwu.edu/geology_facpubs

Part of the Geology Commons

\section{Recommended Citation}

Babcock, Randall Scott; Burmester, Russ R.; Engebretson, David C.; Warnock, A. C.; and Clark, K. P., "A Rifted Margin Origin for the Crescent Basalts and Related Rocks in the Northern Coast Range Volcanic Province, Washington and British-Columbia" (1992). Geology Faculty Publications. 31.

https://cedar.wwu.edu/geology_facpubs/31 


\title{
A Rifted Margin Origin for the Crescent Basalts and Related Rocks in the Northern Coast Range Volcanic Province, Washington and British Columbia
}

\author{
R.S. BABCOCK, R.F. BURMESTER, D.C. ENGEBRETSON, AND A. WARNOCK \\ Department of Geology, Western Washington University, Bellingham.
}

K.P. CLARK

Department of Geology, University of Puget Sound, Tacoma, Washington

\begin{abstract}
The remarkable early to middle Eocene volcanic sequence of the Crescent Formation exposed on the Olympic Peninsula consists predominantly of tholeiitic to minor transitional alkaline basalts with sparse sedimentary interbeds. A composite section measured in the vicinity of the Dosewallips River includes $8.4 \mathrm{~km}$ of pillowed to massive submarine basalts overlain by $7.8 \mathrm{~km}$ of subaerial flows. An upper limit of about $48 \mathrm{Ma}$ on the age of the Crescent basalts is indicated by faunal assemblages in sediments interbedded with the uppermost flows in the sequence and a circa $50 \mathrm{Ma}{ }^{40} \mathrm{Ar} /{ }^{39} \mathrm{Ar}$ age on a leucogabbro from the presumably correlative Bremerton Igneous Complex. Stratigraphically controlled samples collected from throughout the Crescent basalt sequence show that two distinctly different chemical types exist. The lower part of the sequence originated from a relatively depleted mantle course resembling normal $(N)$ to enriched (E)-MORB. The upper flows have a chemistry resembling $E$ MORB to oceanic island tholeiites. This difference could be due to either variable metasomatism of a single source domain, or influx of a separate enriched-mantle source component during the extrusion of the upper part of the sequence. Paleomagnetic measurements indicate that the Crescent basalts have not been significantly rotated, nor translated northwards since their extrusion. Paleotectonic reconstructions show that formation of the Crescent basalts and the Coast Range volcanic province as a whole coincided with a marked increase in the velocity of oblique convergence of the Kula plate with North America at about $60 \mathrm{Ma}$. Other geologic, geochemical, and paleomagnetic data are consistent with the interpretation that extrusion occurred in a basin or series of basins formed by a rift system along the continental margin of North America. Rifting might have been initiated by the influence of a hotspot, an increase in the rate of oblique convergence, or the kinematic effects of the Kula-Farallon ridge as it migrated along the margin. If extrusion is related to the passage of the triple junction, then the Coast Ranges can be considered to be an important tectonic marker for early to middle Eocene plate reconstructions.
\end{abstract}

\section{INTRODUCTION}

One of the most enigmatic aspects of the evolution of the Cordillera is the distinctive tectonic transition from the compressional regime of the Laramide to regional extension during the early to middle Eocene [Heller et al., 1987]. The generally accepted interpretation is that subduction continued throughout this time. period and the compressional regime of the Laramide orogeny was succeeded by regional extension as convergence of the Kula and Farallon plates became more oblique. Extrusion of the Coast Range volcanic province (CRVP) (Figure 1) began during the Paleocene and continued until the late Eocene. These voluminous volcanics previously have been interpreted as a seamount chain extruded on an oceanic plate [Snavely et al., 1968; Duncan, 1982; Wells et al., 1984].

Copyright 1992 by the American Geophysical Union.

Paper number 91JB02926.

0148-0227/92/91JB-02926\$05.00
As the seamounts impinged on the trench, they were accreted to North America, concluding Laramide compression [Duncan, 1982; Wells et al., 1984; Heller, et al., 1987]. It has been proposed that the seamounts were generated by the Yellowstone hotspot, perhaps centered on the Kula-Farallon ridge just west of the margin of North America at about $60 \mathrm{Ma}$ [Duncan, 1982; Wells et al., 1984]. The accreted seamount model explains the great volume of basalts extruded and an apparent progression in the ages of the volcanic centers observed by Duncan [1982]. However, recent detailed studies of the Crescent-Metchosin igneous complex by Brandon and Massey [1985], Massey [1986], and Clark [1989] indicate that these rocks might be better interpreted as the product of continental margin rifting, rather than seamounts on an oceanic plate.

The Crescent Formation, located on the Olympic Peninsula of Washington State (Figure 1), is the most voluminous of the Coast Range volcanic sequences. It includes a section of submarine and subaerial basalts reported by Glassley [1974] and Cady [1975] to be as 


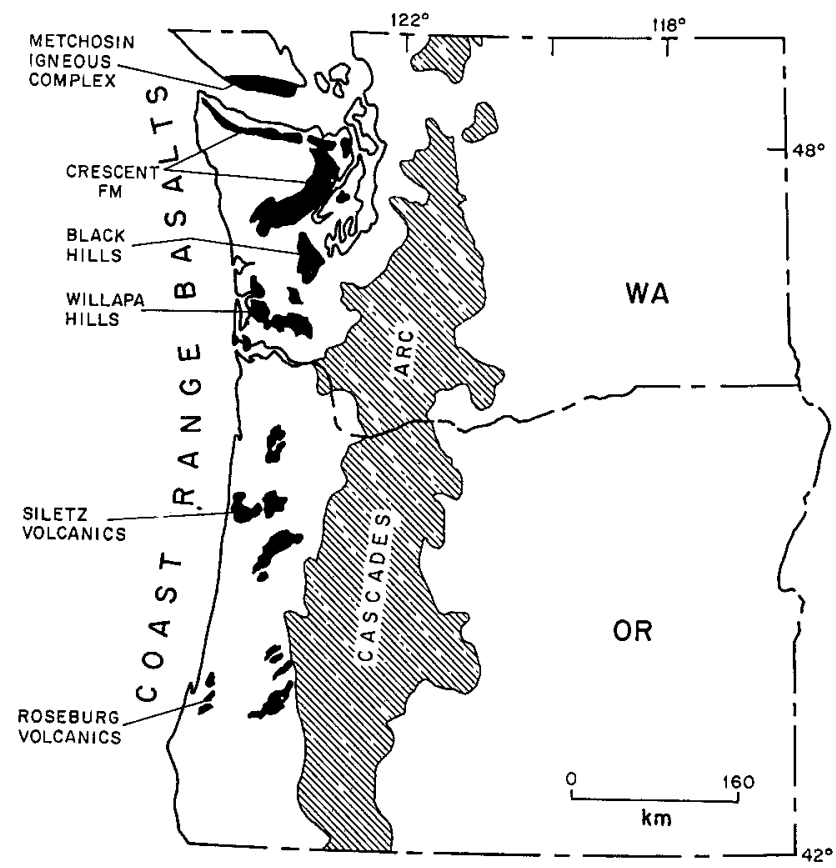

Fig. 1. Distribution of early to middle Eocene volcanic rocks (solid) of the Coast Range Volcanic Province in Oregon, Washington, and southern Vancouver Island. much as $16 \mathrm{~km}$ thick, which makes it one of the thickest accumulations of volcanic rock in the world. It is unique among CRVP sequences, because both the top and the base of the Crescent volcanics are exposed; so the entire sequence can be studied in a depositional context. The purpose of this paper is to report new stratigraphic, paleomagnetic, and geochemical analyses of the Crescent Formation and to assess the implications of these data for basalt petrogensis in the Coast Ranges and the tectonic evolution of this part of the Cordillera.

\section{Geologic SeTring, Petrology, ANd Age}

The Olympic Mountains include two major geologic terranes (Figure 2). The Olympic Core terrane is characterized by highly disrupted (melange and broken formation) marine sedimentary rocks, with minor pillow basalts that have been metamorphosed to prehnite-pumpellyite and greenschist facies in the eastern part [Tabor, 1987]. The Crescent terrane consists of the Blue Mountain unit, the lower to middle Eocene Crescent Formation, and middle Eocene to Pliocene marine sedimentary rocks (Figure 2). Both

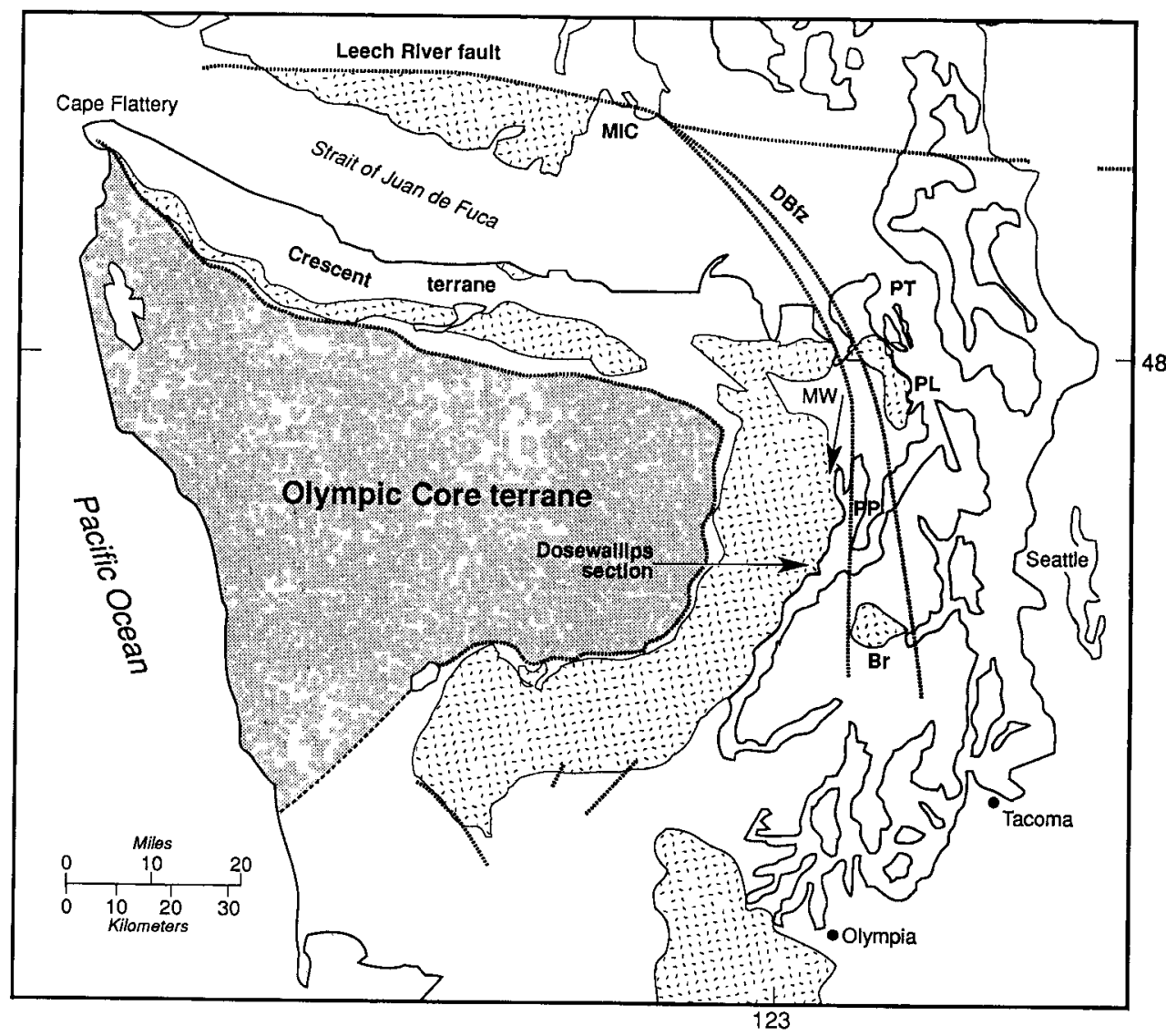

Fig. 2. Distribution of Eocene volcanics (dot pattern) and terrane boundaries on the Olympic Peninsula and vicinity. Abbreviations are MIC, Metchosin Igneous complex; DBfz, Discovery Bay fault zone; PT, Port Townsend; PL, Port Ludlow; MW, Mount Walker; PP, Pulali Point; and $\mathrm{Br}$, Bremerton. Area of Crescent Core terrane is indicated by diagonal lines. Eastern boundary of the Crescent terrane is uncertain and is not shown. 
DOSEWALLIPS COMPOSITE SEgUENCE

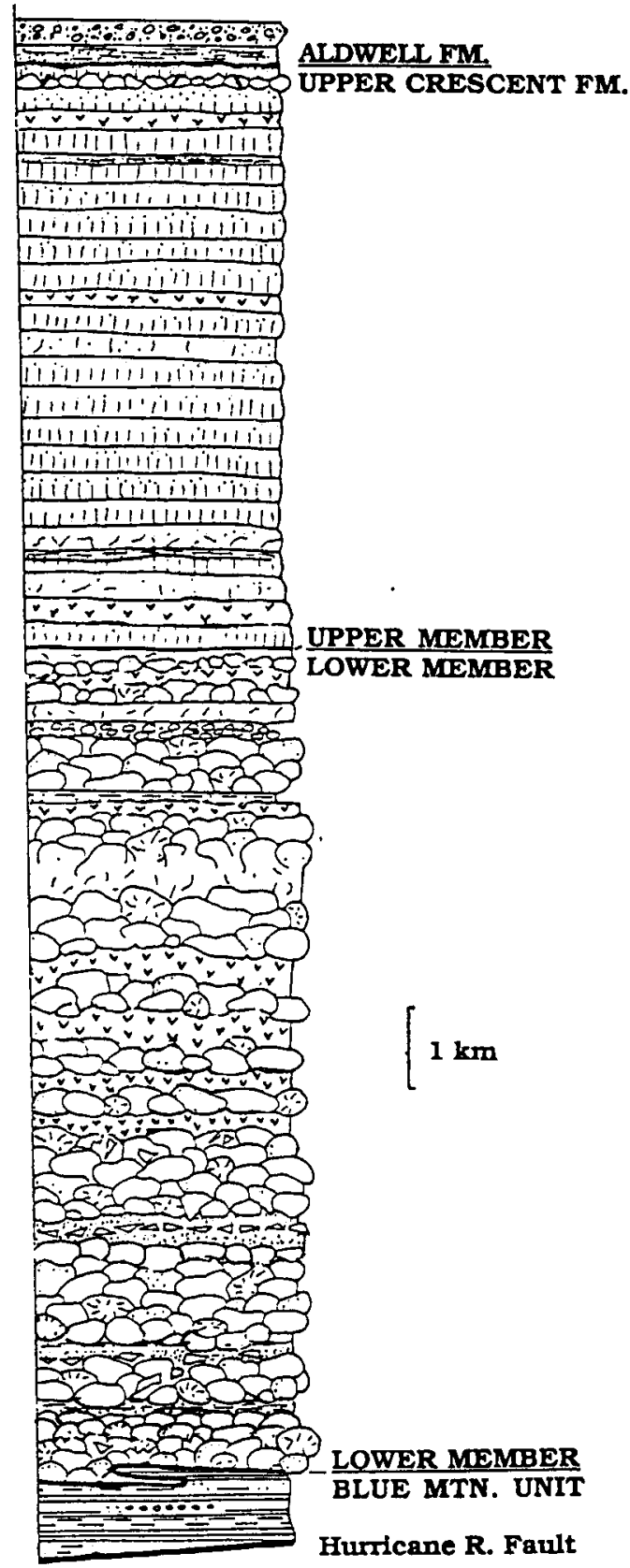

OVERLYING SEDIMENTS

Fossiliferous sandstones, shales, and conglomerates of upper Ulatisian to Narizian age (ca. 50 Ma.)

\section{UPPER MEMBER}

Predominantly columnar to randomly -jointed basalt flows; rare pillows, mainly in uppermost part. Basaltic sills present throughout; dikes much less common. Interbeds include basaltic breccia, sandstone and siltstone, plus foraminiferal limestone. Uppermost flows appear to be inter-bedded with overlying sediments.

\section{LOWER MEMBER}

Predominantly pillowed to massive flows and flow breccias. Massive coarse-grained sills or sheet-flows interspersed, especially in the middle part. Sedimentary interbeds include basaltic sandstone, siltstone, and conglomerate, with minor turbidites. Hyaloclastites and fossiliferous limestones also occur, rarely. Most rocks show prehnite-pumpellyite-facies assemblages in veins and recrystallized volcanic glass. Clino-amphibole. indicating greenschist facies conditions seems to be present only in the uppermost part. The contact with the Blue Mountain unit is not exposed in the Dosewallips valley. Elsewhere, Crescent-type flows appear to be interbedded with the Blue Mtn. unit

\section{BLUE MOUNTAIN UNIT}

Mainly feldspathic and chert-rich turbidites of continental derivation

Fig. 3. Composite stratigraphic column for the Crescent Formation based on mapped traverses in the vicinity of the Dosewallips River valley. Lower member and upper member are defined on the basis of the transition from submarine to subaerial basalts after Tabor and Cady [1978]. Thicknesses of sills and sedimentary interbeds are exaggerated. The contact between the Blue Mountain unit and the Crescent volcanics is not exposed in the Dosewallips section, but to the north Blue Mountain turbidites are clearly interbedded with Crescent basalt. It is likely that structural thickening of the volcanics has occurred, but no field evidence for repetition of the section is apparent.

prehnite-pumpellyite and greenschist facies assemblages have been reported in the lower part of the Crescent volcanics by Glassley [1974]. The Crescent terrane is roughly coeval with the older marine sediments of the Olympic Core terrane, but everywhere separated from them by faults [Tabor, 1987].

The Crescent Formation (Figure 3 ) is underlain by a turbidite-dominated basal unit of volcaniclastic 
sandstone, argillite, and conglomerate known as the Blue Mountain unit. Two distinct petrofacies occur: one a plagioclase-rich feldspathic arenite, probably derived from the Coast Plutonic Complex; and the other a chert-rich lithic arenite that matches a nearby San Juan Island source [Einarsen, 1987]. Submarine basalts, composing the lower part of the Crescent volcanics, are partly interbedded with the terrigenous Blue Mountain unit [Cady, 1975; Tabor, 1987]. Proximity to North America at the time of extrusion is also indicated by interbeds containing clasts, up to $3 \mathrm{~m}$ in diameter, of $65 \mathrm{Ma}$ quartz diorite [Cady, 1975]. The Metchosin Igneous Complex on Vancouver Island is correlative to and probably coextensive with the Crescent volcanics of the northern Olympic Peninsula [Muller, 1980; Massey, 1986]. The Metchosin includes both submarine and subaerial flows as well as the gabbros and sheeted dikes of the Sooke intrusive center [Massey, 1986]. A similar intrusive center and associated flows, inferred to be correlative with the Crescent volcanics [Clark, 1989], are located near Bremerton on the Kitsap Peninsula (Figure 2).

Our work in the Crescent Formation is concentrated in the vicinity of the Dosewallips River (Figure 2), which has cut a valley roughly perpendicular to the strike of the thickest part of the Crescent volcanics. Flows in this section are generally near vertical with tops facing east. Strikes mainly follow the pattern of the outcrop swath, with only a few fold structures apparent. The lower part of the section consists predominantly of pillowed to massive submarine basalt flows sparsely interbedded with volcaniclastics, hyaloclastites, and foraminiferal limestone. In contrast, the upper part of the section consists of massive to columnar-jointed, shallow water and subaerial basalt flows that commonly show oxidized tops and paleosols [Glassley, 1974; Cady, 1975]. A tectonic contact, marked by a discontinuity in metamorphic facies and brecciated transition zone, was reported to exist between the upper and lower parts of the volcanic sequence [Glassley, 1974]. However, subsequent mapping of the area by Cady [1975] and Tabor and
Cady [1978] revealed no credible evidence for such a fault. Cady [1975] also reported that no evidence could be found for a consistent break in metamorphic grade or structural style between the upper and lower parts of the section. Our reconnaissance structural studies along recently constructed logging roads in the Dosewallips area found both normal and thrust faulting on a small scale but no major through-going structures. Zones of intense deformation were found at various stratigraphic levels. Tectonic disruption within the Dosewallips section is undoubtedly far more complex than the simple thrust of upper member over lower member described by Glassley [1974].

We have measured a "composite volcanic sequence" from 11 separate traverses trending roughly perpendicular to strike. The measured section extends from the base of the volcanics at Dosewallips Camp to the uppermost flows at Pulali Point on Hood Canal (Figure 3). The thickness of the submarine part of the Crescent volcanics measured on this composite sequence (to be abbreviated DCVS) is $8.4 \mathrm{~km}$, while that of the subaerial section is $7.8 \mathrm{~km}$. These exceptional thicknesses cannot be considered stratigraphic, because it was impossible to detect the existence of folds or faults in the covered areas between outcrops. Detailed studies are underway to establish the nature of structural thickening of the DCVS, which was not apparent from our data.

The age range for extrusion of the Crescent volcanics is not well established because most $\mathrm{K} / \mathrm{Ar}$ ages probably have been reset [Duncan, 1982]. Only five reliable whole rock ages are available. These include a ${ }^{40} \mathrm{Ar} /{ }^{39} \mathrm{Ar}$ fusion age of $57.8 \pm 0.8 \mathrm{Ma}$ for a basalt flow from the Metchosin igneous complex and a ${ }^{40} \mathrm{Ar} /{ }^{39} \mathrm{Ar}$ isochron age of $55.4 \pm 3.2 \mathrm{Ma}$ for a flow in the Bremerton Igneous Complex given by Duncan [1982]. Clark [1989] presented new ${ }^{40} \mathrm{Ar} /{ }^{39} \mathrm{Ar}$ total fusion ages of $50.4 \pm 0.6 \mathrm{Ma}$ and $49.2 \pm 0.8$ plus a ${ }^{40} \mathrm{Ar} /{ }^{39} \mathrm{Ar}$ isochron age of $50.3 \pm 1.5$ for a Bremerton leucogabbro (Table 1). Neither the Metchosin nor the Bremerton flows are part of the Crescent Formation (sensu stricto), but they are probably correlative.

TABLE 1. K/Ar Age Determinations on the Bremerton Leucogabbro Sample From the Bremerton Igneous Complex

\begin{tabular}{llll} 
& Rad. ${ }^{40} \mathrm{Ar} /{ }^{39} \mathrm{Ar} \%$ & $\% /$ Rad, & Age, m.y. \\
\hline Experiment 1 & $\begin{array}{l}8.873 \\
(J=0.003193)\end{array}$ & 50.6 & $50.4 \pm 0.6$ \\
Experiment 2 & 9.113 & 45.4 & $49.2 \pm 0.8$ \\
Isochron (five gas increments) & & & $5.03 \pm 1.5$ \\
& & 40.36 intercept $291 \pm 7$ & \\
\hline
\end{tabular}


TABLE 2. Major and Trace Element Analysis for Dosewallips Volcanic Sequence

Sample

\begin{tabular}{cccccccccccccccc}
\hline DU52 & DU51 & DU50 & DU49 & DU48 & DU47 & DU46 & DUs10 & DU45 & DUs09 & DU44 & DU43 & DU42 & DU41 & DU40 & DU39 \\
& & & & & & & & & & & & & & & \\
& & & & & & & & & & & & \\
48.26 & 49.84 & 49.42 & 50.12 & 49.1 & 48.69 & 52.06 & 48.88 & 48.19 & 48.26 & 48.86 & 49.07 & 50.04 & 49.37 & 47.72 & 49.91 \\
1.41 & 2.24 & 2.47 & 2.1 & 2.36 & 1.85 & 2.1 & 1.84 & 1.8 & 1.83 & 1.85 & 1.86 & 1.71 & 1.74 & 2.18 & 1.97 \\
17.77 & 14.44 & 13.96 & 14.2 & 14.8 & 14.94 & 13.74 & 14.94 & 14.95 & 14.89 & 14.03 & 14.35 & 15.53 & 15.23 & 13.8 & 14.16 \\
8.8 & 11.35 & 12.64 & 11.05 & 10.15 & 11.18 & 10.53 & 11.29 & 10.98 & 11.12 & 11.99 & 10.87 & 10.95 & 11.31 & 12.19 & 11.83 \\
0.16 & 0.16 & 0.29 & 0.17 & 0.23 & 0.21 & 0.46 & 0.23 & 0.29 & 0.22 & 0.23 & 0.2 & 0.2 & 0.21 & 0.19 & 0.22 \\
8.15 & 6.51 & 6.28 & 7.12 & 6.84 & 6.76 & 5.7 & 6.76 & 6.67 & 6.55 & 7.36 & 7.31 & 5.79 & 6.03 & 5.96 & 6.71 \\
10.81 & 9.87 & 8.41 & 10.04 & 11.89 & 12.12 & 10.45 & 12.39 & 11.99 & 12.29 & 10.84 & 12.24 & 11.76 & 11.4 & 10.88 & 10.42 \\
2.9 & 3.87 & 4.34 & 3.72 & 3.13 & 2.73 & 30.2 & 2.75 & 2.93 & 2.8 & 3.13 & 2.34 & 2.8 & 3.05 & 3.65 & 3.66 \\
0.42 & 0.19 & 0.43 & 0.29 & 0.12 & 0.12 & 0.16 & 0.11 & 0.11 & 0.12 & 0.24 & 0.18 & 0.13 & 0.16 & 0.12 & 0.11 \\
0.15 & 0.29 & 0.35 & 0.27 & 0.25 & 0.19 & 0.24 & 0.19 & 0.19 & 0.19 & 0.18 & 0.18 & 0.18 & 0.18 & 0.22 & 0.2 \\
98.83 & 98.76 & 98.59 & 98.83 & 98.87 & 98.79 & 98.46 & 99.38 & 98.1 & 98.27 & 98.71 & 98.6 & 99.09 & 98.68 & 96.91 & 99.19
\end{tabular}

\begin{tabular}{|c|c|c|c|c|c|c|c|c|c|c|c|c|c|c|c|c|}
\hline $\mathrm{Ni}$ & 116 & 41 & 39 & 43 & 78 & 60 & 47 & 59 & 56 & 58 & 54 & 56 & 46 & 47 & 55 & 51 \\
\hline $\mathrm{Cr}$ & 187 & 144 & 89 & 145 & 221 & 235 & 71 & 239 & 239 & 237 & 163 & 183 & 79 & 76 & 138 & 97 \\
\hline $\mathrm{Sc}$ & 35 & 46 & 37 & 42 & 44 & 43 & 41 & 43 & 42 & 43 & 44 & 44 & 41 & 44 & 42 & 44 \\
\hline V & 237 & 339 & 342 & 330 & 389 & 318 & 336 & 322 & 311 & 313 & 319 & 333 & 346 & 350 & 352 & 378 \\
\hline $\mathrm{Ba}$ & 130 & 45 & 112 & 50 & 15 & 11 & 37 & 11 & 20 & 2 & 1 & 3 & 17 & 5 & 24 & 29 \\
\hline $\mathbf{R b}$ & 5 & 1 & 2 & 3 & 1 & 1 & 2 & 1 & 2 & 2 & 2 & 1 & 1 & 2 & 2 & 2 \\
\hline $\mathrm{Sr}$ & 630 & 310 & 369 & 216 & 209 & 211 & 201 & 209 & 205 & 216 & 201 & 190 & 190 & 193 & 409 & 312 \\
\hline $\mathrm{Zr}$ & 113 & 176 & 212 & 154 & 145 & 118 & 140 & 120 & 117 & 121 & 117 & 113 & 110 & 112 & 140 & 126 \\
\hline$Y$ & 24 & 43 & 48 & 37 & 37 & 30 & 35 & 29 & 28 & 30 & 28 & 27 & 32 & 32 & 33 & 36 \\
\hline $\mathrm{Nb}$ & 9.3 & 17.4 & 20.2 & 14.6 & 12.1 & 13.9 & 13 & 11.2 & 11.3 & 11.9 & 13.9 & 12.8 & 11.3 & 10.5 & 15.3 & 13.2 \\
\hline $\mathbf{G a}$ & 15 & 18 & 19 & 17 & 18 & 17 & 20 & 17 & 18 & 18 & 21 & 19 & 19 & 17 & 16 & 17 \\
\hline $\mathrm{Cu}$ & 52 & 144 & 138 & 75 & 187 & 153 & 217 & 152 & 147 & 157 & 77 & 81 & 183 & 220 & 117 & 240 \\
\hline $\mathrm{Zn}$ & 73 & 106 & 116 & 106 & 99 & 86 & 123 & 87 & 83 & 90 & 87 & 87 & 93 & 119 & 102 & 97 \\
\hline $\mathrm{Pb}$ & 0 & 0 & 1 & 4 & 1 & 1 & 4 & 0 & 2 & 3 & 0 & 1 & 0 & 0 & 0 & 0 \\
\hline $\mathrm{La}$ & 3 & 12 & 14. & 23 & 12 & 3 & 20 & 8 & 0 & 15 & 0 & 5 & 15 & 3 & 10 & 2 \\
\hline $\mathrm{Ce}$ & 20 & 26 & 43 & 46 & 35 & 30 & 30 & 20 & 42 & 33 & 41 & 42 & 42 & 38 & 40 & 40 \\
\hline Th & 1 & 1 & 1 & 4 & 1 & 0 & 0 & 0 & 2 & 2 & 3 & 3 & 0 & 0 & 1 & 2 \\
\hline $\begin{array}{l}\text { Strat, } m \\
\text { Type }\end{array}$ & $\begin{array}{l}16,220 \\
\text { cf }\end{array}$ & $\begin{array}{l}16,210 \\
\text { cf }\end{array}$ & $\begin{array}{l}16,200 \\
\text { cf }\end{array}$ & $\begin{array}{l}16,195 \\
\text { cf }\end{array}$ & $\begin{array}{l}16,065 \\
\text { pf }\end{array}$ & $\begin{array}{l}16,005 \\
\text { cf }\end{array}$ & $\begin{array}{l}15,995 \\
\mathrm{pb}\end{array}$ & $\begin{array}{l}15,985 \\
\text { dike }\end{array}$ & $\begin{array}{c}15,980 \\
\mathrm{pb}\end{array}$ & $\begin{array}{l}15,975 \\
\mathrm{si} / \mathrm{sh}\end{array}$ & $\begin{array}{c}15,800 \\
\text { cf }\end{array}$ & $\begin{array}{c}15,780 \\
\text { cf }\end{array}$ & $\begin{array}{c}15,080 \\
\text { cf }\end{array}$ & $\begin{array}{c}15,075 \\
\text { cf }\end{array}$ & $\begin{array}{c}14,020 \\
\text { cf }\end{array}$ & $\begin{array}{c}13,980 \\
\text { ef }\end{array}$ \\
\hline
\end{tabular}


TABLE 2. (Continued)

\begin{tabular}{|c|c|c|c|c|c|c|c|c|c|c|c|c|c|c|c|c|}
\hline \multicolumn{17}{|c|}{ Sample } \\
\hline & DU38 & DU37 & DU36 & DUs08 & DU35 & DU34 & DU33 & DU32 & DU31 & DU30 & DU29 & DU28 & DU27 & DU26 & DU25 & DU24 \\
\hline $\mathrm{SiO}_{2}$ & 47.37 & 53.7 & 48.33 & 48.89 & 49.92 & 49.03 & 48.43 & 50.22 & 49.35 & 48.45 & 48.1 & 49.11 & 49.7 & 48.86 & 48.82 & 48.32 \\
\hline $\mathrm{TiO}_{2}$ & 1.65 & 2.12 & 2.13 & 1.55 & 2.08 & 1.94 & 1.51 & 2.1 & 2.32 & 1.82 & 2.02 & 2.47 & 1.64 & 1.85 & 2.31 & 1.88 \\
\hline $\mathrm{Al}_{2} \mathrm{O}_{3}$ & 15.56 & 11.48 & 13.59 & 16.91 & 13.89 & 15.22 & 13.92 & 14.57 & 13.89 & 16.07 & 15.27 & 13.81 & 15.11 & 15 & 14.38 & 15.04 \\
\hline $\mathrm{FeOt}$ & 10.5 & 14.16 & 12.09 & 9.73 & 10.83 & 11.29 & 12.15 & 11.74 & 11.87 & 10.51 & 10.99 & 11.47 & 8.43 & 10.9 & 12.47 & 10.69 \\
\hline $\mathrm{MnO}$ & 0.22 & 0.22 & 0.18 & 0.17 & 0.21 & 0.18 & 0.17 & 0.22 & 0.2 & 0.17 & 0.18 & 0.19 & 0.15 & 0.19 & 0.22 & 0.21 \\
\hline $\mathrm{MgO}$ & 8.21 & 4.68 & 6.39 & 7.04 & 6.8 & 5.98 & 7.33 & 6.2 & 5.95 & 7.5 & 6.66 & 6.51 & 7.63 & 7.79 & 7.16 & 7.9 \\
\hline $\mathrm{CaO}$ & 12.17 & 9 & 10.5 & 9.97 & 11 & 11.94 & 9.78 & 9.96 & 9.67 & 10.78 & 10.68 & 10.03 & 10.77 & 11.35 & 11.58 & 12.18 \\
\hline $\mathrm{Na}_{2} \mathrm{O}$ & 2.27 & 2.91 & 3.71 & 2.93 & 3.54 & 2.69 & 4.42 & 4.16 & 3.72 & 3.1 & 3.19 & 3.11 & 3.63 & 3 & 2.24 & 2.14 \\
\hline $\mathrm{K}_{2} \mathrm{O}$ & 0.2 & 0.1 & 0.2 & 1.05 & 0.27 & 0.2 & 0.52 & 0.09 & 0.5 & 0.39 & 0.39 & 0.74 & 0.49 & 0.14 & 0.2 & 0.24 \\
\hline $\mathrm{P}_{2} \mathrm{O}_{5}$ & 0.16 & 0.38 & 0.2 & 0.16 & 0.21 & 0.21 & 0.11 & 0.22 & 0.25 & 0.19 & 0.21 & 0.27 & 0.16 & 0.18 & 0.24 & 0.18 \\
\hline Total & 98.31 & 98.75 & 97.32 & 98.4 & 98.75 & 98.68 & 98.34 & 99.48 & 97.72 & 98.98 & 97.69 & 97.71 & 97.71 & 99.26 & 99.62 & 98.78 \\
\hline $\mathrm{Ni}$ & 95 & 14 & 45 & 67 & 60 & 56 & 62 & 52 & 50 & 104 & 69 & 68 & 98 & 75 & 86 & 106 \\
\hline $\mathrm{Cr}$ & 270 & 13 & 61 & 192 & 164 & 116 & 265 & 84 & 120 & 206 & 157 & 202 & 262 & 187 & 248 & 308 \\
\hline $\mathrm{Sc}$ & 40 & 38 & 42 & 39 & 43 & 41 & 48 & 39 & 43 & 36 & 38 & 34 & 35 & 40 & 42 & 41 \\
\hline V & 288 & 300 & 355 & 275 & 351 & 332 & 305 & 359 & 375 & 292 & 329 & 376 & 279 & 322 & 360 & 293 \\
\hline $\mathrm{Ba}$ & 10 & 6 & 66 & 140 & 70 & 5 & 42 & 15 & 65 & 22 & 70 & 112 & 26 & 58 & 69 & 69 \\
\hline $\mathrm{Rb}$ & 2 & 2 & 3 & 16 & 4 & 3 & 11 & 1 & 5 & 4 & 6 & 9 & 7 & 1 & 2 & 3 \\
\hline $\mathrm{Sr}$ & 216 & 131 & 392 & 347 & 703 & 213 & 112 & 627 & 414 & 300 & 267 & 297 & 331 & 364 & 216 & 223 \\
\hline $\mathrm{Zr}$ & 99 & 217 & 133 & 105 & 142 & 127 & 86 & 148 & 164 & 123 & 136 & 162 & 109 & 119 & 146 & 116 \\
\hline $\mathrm{Y}$ & 24 & 69 & 36 & 24 & 30 & 32 & 27 & 34 & 37 & 27 & 28 & 35 & 21 & 25 & 30 & 24 \\
\hline $\mathrm{Nb}$ & 12 & 27 & 15.7 & 12.5 & 15.6 & 12.9 & 8.6 & 15.6 & 17.6 & 14.3 & 19.1 & 20.4 & 15.9 & 14 & 18 & 14 \\
\hline Ga & 17 & 18 & 18 & 15 & 15 & 20 & 16 & 17 & 20 & 20 & 20 & 20 & 16 & 17 & 21 & 19 \\
\hline $\mathrm{Cu}$ & 54 & 310 & 126 & 48 & 130 & 51 & 118 & 252 & 146 & 175 & 126 & 134 & 76 & 261 & 283 & 130 \\
\hline $\mathrm{Zn}$ & 77 & 86 & 98 & 71 & 97 & 94 & 74 & 121 & 106 & 83 & 85 & 101 & 70 & 110 & 115 & 86 \\
\hline $\mathrm{Pb}$ & 0 & 0 & 0 & 1 & 1 & 1 & 0 & 1 & 2 & 0 & 1 & 1 & 1 & nd & nd & nd \\
\hline La & 10 & 19 & 2 & 0 & 14 & 8 & 6 & 13 & 12 & 9 & 12 & 10 & 1 & nd & nd & nd \\
\hline $\mathrm{Ce}$ & 29 & 45 & 27 & 26 & 45 & 35 & 18 & 37 & 47 & 29 & 47 & 68 & 28 & nd & nd & nd \\
\hline Th & 1 & 3 & 0 & 4 & 1 & 0 & 3 & 2 & 0 & 1 & 1 & 0 & 0 & nd & nd & nd \\
\hline $\begin{array}{l}\text { Strat, m } \\
\text { Type }\end{array}$ & $\begin{array}{l}13,960 \\
\text { cf }\end{array}$ & $\begin{array}{l}13,955 \\
\text { cf }\end{array}$ & $\begin{array}{c}13,525 \\
\mathrm{mf}\end{array}$ & $\begin{array}{l}13,490 \\
\mathrm{si} / \mathrm{sh}\end{array}$ & $\begin{array}{l}13,315 \\
\text { cf }\end{array}$ & $\begin{array}{c}13,310 \\
\mathrm{mf}\end{array}$ & $\begin{array}{l}13,300 \\
\text { cf }\end{array}$ & $\begin{array}{l}13,275 \\
\text { cf }\end{array}$ & $\begin{array}{l}13,240 \\
\text { cf }\end{array}$ & $\begin{array}{l}13,205 \\
\text { cf }\end{array}$ & $\begin{array}{l}13,075 \\
\text { cf }\end{array}$ & $\begin{array}{c}13,000 \\
\text { cf }\end{array}$ & $\begin{array}{l}12,530 \\
\text { ef }\end{array}$ & $\begin{array}{l}12,500 \\
\text { cf }\end{array}$ & $\begin{array}{l}11,720 \\
\text { cf }\end{array}$ & $\begin{array}{c}11,515 \\
\text { cf }\end{array}$ \\
\hline
\end{tabular}


TABLE 2. (Continued)

\begin{tabular}{|c|c|c|c|c|c|c|c|c|c|c|c|c|c|c|c|c|}
\hline \multicolumn{17}{|c|}{ Sample } \\
\hline & DU23 & DU22 & DU21 & DUs07 & DUs06 & DU20 & DL19 & DL18 & DL17 & DL16 & DL15 & DL14 & DL13 & DL12 & DL11 & DLs05 \\
\hline $\mathrm{SiO}_{2}$ & 48.74 & 46.99 & 50.32 & 47.86 & 48.09 & 47.95 & 48.64 & 46.09 & 46.49 & 48.44 & 57.2 & 41.47 & 48.57 & 54.82 & 50.56 & 51.85 \\
\hline $\mathrm{TiO}_{2}$ & 2.65 & 1.94 & 1.67 & 2.5 & 2.54 & 1.65 & 2.4 & 1.58 & 1.58 & 1.76 & 1.88 & 2.29 & 2.91 & 2.47 & 2 & 1.82 \\
\hline $\mathrm{Al}_{2} \mathrm{O}_{3}$ & 13.96 & 13.93 & 13.75 & 14.21 & 12.86 & 14.18 & 12.57 & 13.44 & 15.14 & 14.03 & 12.74 & 13.44 & 15.59 & 13.15 & 12.01 & 12.21 \\
\hline FeOt & 13.38 & 12.82 & 10.11 & 12.98 & 13.69 & 10.98 & 12.77 & 10.75 & 11.61 & 12.93 & 12.09 & 12.82 & 20.85 & 12.3 & 13.81 & 14.85 \\
\hline $\mathrm{MnO}$ & 0.21 & 0.2 & 0.16 & 0.22 & 0.22 & 0.19 & 0.19 & 0.18 & 0.22 & 0.23 & 0.21 & 0.22 & 0.33 & 0.19 & 0.22 & 0.26 \\
\hline $\mathrm{MgO}$ & 6.57 & 8.17 & 8.17 & 5.78 & 5.87 & 8.36 & 5.39 & 7.58 & 8.61 & 7.42 & 2.27 & 6.24 & 3.91 & 2.66 & 4.53 & 5.21 \\
\hline $\mathrm{CaO}$ & 10.04 & 9.79 & 10.11 & 10.42 & 9.51 & 11.37 & 10.59 & 10.8 & 11.49 & 9.46 & 6.05 & 9.43 & 6.77 & 5.49 & 9.21 & 7.21 \\
\hline $\mathrm{Na}_{2} \mathrm{O}$ & 3.19 & 3.4 & 3.7 & 3.17 & 3.91 & 2.56 & 3.99 & 2.85 & 1.77 & 3.27 & 4.92 & 4.03 & 1.83 & 5.94 & 4.18 & 4.66 \\
\hline $\mathrm{K}_{2} \mathrm{O}$ & 0.39 & 0.04 & 0.12 & 0.57 & 0.11 & 0.2 & 0.03 & 0.17 & 0.22 & 0.43 & 0.64 & 0.42 & 1.95 & 0.76 & 0.64 & 0.02 \\
\hline $\mathrm{P}_{2} \mathrm{O}_{5}$ & 0.26 & 0.08 & 0.16 & 0.24 & 0.26 & 0.15 & 0.317 & 0.14 & 0.1 & 0.15 & 0.58 & 0.26 & 0.96 & 0.42 & 0.19 & 0.18 \\
\hline Total & 99.39 & 97.36 & 98.27 & 97.95 & 97.06 & 97.59 & 96.89 & 93.58 & 97.23 & 98.12 & 98.58 & 97.72 & 96.57 & 98.2 & 97.35 & 98.27 \\
\hline $\mathrm{Ni}$ & 45 & 102 & 105 & 37 & 38 & 92 & 32 & 89 & 102 & 49 & 2 & 48 & 0 & 1 & 31 & 16 \\
\hline $\mathrm{Cr}$ & 82 & 252 & 285 & 47 & 49 & 272 & 83 & 257 & 152 & 69 & 1 & 92 & 0 & 1 & 49 & 22 \\
\hline $\mathrm{Sc}$ & 36 & 39 & 44 & 42 & 46 & 47 & 37 & 46 & 44 & 55 & 20 & 50 & 37 & 30 & 51 & 45 \\
\hline v & 368 & 273 & 321 & 368 & 361 & 327 & 363 & 326 & 419 & 434 & 55 & 477 & 61 & 104 & 426 & 499 \\
\hline $\mathrm{Ba}$ & 141 & 4 & 9 & 105 & 1 & 32 & 1 & 29 & 9 & 1 & 71 & 1 & 299 & 100 & 30 & 1 \\
\hline $\mathbf{R b}$ & 3 & 2 & 2 & 9 & 2 & 3 & 0 & 4 & 5 & 8 & 20 & 8 & 53 & 8 & 9 & 2 \\
\hline $\mathbf{S r}$ & 311 & 217 & 285 & 346 & 282 & 210 & 91 & 278 & 143 & 174 & 154 & 146 & 154 & 109 & 83 & 30 \\
\hline $\mathrm{Zr}$ & 171 & 115 & 104 & 132 & 139 & 94 & 170 & 97 & 74 & 99 & 294 & 138 & 522 & 299 & 122 & 97 \\
\hline $\mathbf{Y}$ & 33 & 21 & 25 & 32 & 32 & 26 & 47 & 25 & 25 & 42 & 112 & 51 & 177 & 103 & 46 & 48 \\
\hline $\mathrm{Nb}$ & 18 & 12.5 & 10.2 & 16 & 15.9 & 9.5 & 25.9 & 7.8 & 9.5 & 5.7 & 22.2 & 11.2 & 41.2 & 25.4 & 7.4 & 6 \\
\hline Ga & 23 & 20 & 15 & 22 & 14 & 19 & 19 & 15 & 17 & 17 & 23 & 18 & 34 & 19 & 14 & 19 \\
\hline $\mathrm{Cu}$ & 140 & 124 & 138 & 245 & 237 & 186 & 109 & 194 & 272 & 112 & 68 & 98 & 15 & 0 & 131 & 87 \\
\hline $\mathrm{Zn}$ & 128 & 113 & 76 & 113 & 98 & 93 & 107 & 82 & 101 & 103 & 193 & 105 & 224 & 130 & 106 & 130 \\
\hline $\mathrm{Pb}$ & nd & 1 & 1 & 4 & 0 & 2 & 4 & 1 & 2 & 3 & 3 & 2 & 3 & 2 & 0 & 2 \\
\hline $\mathrm{La}$ & nd & 8 & 2 & 11 & 2 & 1 & 3 & 0 & 0 & 0 & 29 & 6 & 18 & 16 & 0 & 0 \\
\hline $\mathrm{Ce}$ & nd & 30 & 37 & 34 & 39 & 26 & 41 & 40 & 18 & 24 & 67 & 36 & 90 & 60 & 20 & 33 \\
\hline $\mathrm{Th}$ & nd & 2 & 0 & 1 & 1 & 2 & 0 & 0 & 3 & 1 & 2 & 0 & 4 & 0 & 2 & 0 \\
\hline Strat, m & 10,735 & 10,645 & 9,335 & 8,720 & 8,690 & 8,420 & 8,295 & 8,290 & 7,930 & 7,480 & 7,440 & 7,415 & 7,350 & 7,305 & 7,030 & 6,420 \\
\hline Type & $\mathrm{mf}$ & $\mathrm{mf}$ & $\mathrm{mf}$ & si/sh & si/sh & $\mathrm{mf}$ & pf & pf & pf & pf & pf & $\mathrm{pf}$ & pf & pf & pf & si/sh \\
\hline
\end{tabular}


TABLE 2. (Continued)

\begin{tabular}{|c|c|c|c|c|c|c|c|c|c|c|c|c|c|c|c|}
\hline \multicolumn{16}{|c|}{ Sample } \\
\hline & DL10 & DLs04 & DLs03 & DLO9 & DL08 & DLs02 & DL07 & DL06 & DLO5 & DLs01 & DL04r & DLO4c & DL03 & DL02 & DL01 \\
\hline $\mathrm{SiO}_{2}$ & 46.75 & 49.42 & 49.29 & 49.46 & 48.57 & 50.37 & 48.36 & 49.69 & 47.92 & 48.34 & 47.68 & 48.45 & 47.08 & 49.51 & 50.52 \\
\hline $\mathrm{TiO}_{2}$ & 2.05 & 1.37 & 1.36 & 0.87 & 1.42 & 1.64 & 1.7 & 1.58 & 1.69 & 1.43 & 1.09 & 1.15 & 1.04 & 1.4 & 0.84 \\
\hline $\mathrm{Al}_{2} \mathrm{O}_{3}$ & 12.84 & 13.87 & 13.51 & 13.93 & 15.31 & 13.17 & 15.17 & 14.62 & 15.01 & 14.47 & 15.04 & 15.16 & 15.71 & 15.28 & 14.97 \\
\hline $\mathrm{FeOt}$ & 17.39 & 11.96 & 11.98 & 9.71 & 12.62 & 12.4 & 13.46 & 12.38 & 14.19 & 11.4 & 10.53 & 9.81 & 8.78 & 11.82 & 9.54 \\
\hline $\mathrm{MnO}$ & 0.34 & 0.21 & 0.21 & 0.19 & 0.21 & 0.2 & 0.21 & 0.23 & 0.21 & 0.2 & 0.19 & 0.18 & 0.16 & 0.24 & 0.19 \\
\hline $\mathrm{MgO}$ & 6.02 & 7.03 & 6.99 & 8.99 & 7.02 & 7.04 & 7.57 & 10.67 & 7.36 & 7.21 & 9.05 & 7.51 & 10.25 & 6.94 & 9.08 \\
\hline $\mathrm{CaO}$ & 6.94 & 10.01 & 9.87 & 9.94 & 8.2 & 8.17 & 6.82 & 5.31 & 6.96 & 11.93 & 12.17 & 12.54 & 9.6 & 8.12 & 9.2 \\
\hline $\mathrm{Na}_{2} \mathrm{O}$ & 3.61 & 3.42 & 3.65 & 3.32 & 3.7 & 4.14 & 2.92 & 1.91 & 2.84 & 2.59 & 2.28 & 2.66 & 1.19 & 3.22 & 2.71 \\
\hline $\mathrm{K}_{2} \mathrm{O}$ & 0.37 & 0.41 & 0.19 & 0.14 & 0.39 & 0.7 & 0.31 & 0.24 & 0.32 & 0.33 & 0.11 & 0.12 & 2.93 & 1.51 & 1.58 \\
\hline $\mathrm{P}_{2} \mathrm{O}_{5}$ & 0.22 & 0.12 & 0.12 & 0.08 & 0.09 & 0.14 & 0.18 & 0.11 & 0.18 & 0.12 & 0.09 & 0.09 & 0.25 & 0.16 & 0.09 \\
\hline Total & 96.53 & 97.82 & 97.17 & 96.63 & 97.53 & 97.97 & 96.7 & 96.74 & 96.68 & 98.02 & 98.23 & 97.67 & 96.99 & 98.2 & 98.72 \\
\hline $\mathrm{Ni}$ & 14 & 54 & 57 & 107 & 67 & 55 & 51 & 53 & 50 & 75 & 82 & 83 & 186 & 90 & 68 \\
\hline $\mathrm{Cr}$ & 20 & 99 & 102 & 157 & 122 & 120 & 149 & 155 & 150 & 165 & 306 & 317 & 475 & 147 & 176 \\
\hline Sc & 53 & 54 & 51 & 40 & 48 & 52 & 46 & 35 & 46 & 58 & 40 & 46 & 41 & 55 & 51 \\
\hline v & 546 & 384 & 378 & 272 & 430 & 428 & 341 & 316 & 339 & 345 & 288 & 292 & 245 & 324 & 259 \\
\hline $\mathrm{Ba}$ & 10 & 14 & 3 & 1 & 1 & 1 & 33 & 29 & 15 & 1 & 9 & 1 & 256 & 24 & 91 \\
\hline $\mathbf{R b}$ & 4 & 7 & 3 & 3 & 14 & 16 & 2 & 4 & 4 & 4 & 1 & 4 & 57 & 37 & 34 \\
\hline $\mathrm{Sr}$ & 41 & 147 & 125 & 152 & 119 & 142 & 220 & 190 & 220 & 175 & 161 & 164 & 65 & 107 & 162 \\
\hline $\mathrm{Zr}$ & 115 & 79 & 79 & 53 & 69 & 86 & 174 & 160 & 176 & 96 & 69 & 71 & 68 & 77 & 54 \\
\hline$Y$ & 59 & 35 & 35 & 22 & 33 & 43 & 56 & 51 & 58 & 34 & 26 & 24 & 25 & 37 & 25 \\
\hline $\mathrm{Nb}$ & 6.2 & 6.4 & 5.6 & 4 & 4.2 & 5.7 & 15 & 13 & 14.8 & 6.4 & 5.7 & 5.5 & 10.3 & 5.6 & 3.8 \\
\hline $\mathrm{Ga}$ & 20 & 18 & 15 & 10 & 16 & 16 & 20 & 16 & 16 & 18 & 16 & 12 & 14 & 16 & 15 \\
\hline $\mathrm{Cu}$ & 110 & 148 & 145 & 145 & 151 & 143 & 146 & 153 & 119 & 145 & 134 & 149 & 168 & 17 & 169 \\
\hline $\mathrm{Zn}$ & 133 & 83 & 83 & 66 & 91 & 90 & 115 & 108 & 100 & 76 & 70 & 62 & 57 & 97 & 91 \\
\hline $\mathrm{Pb}$ & 2 & 1 & 0 & 3 & 2 & 2 & 2 & 0 & 0 & 2 & 1 & 0 & 3 & 1 & 2 \\
\hline La & 0 & 6 & 0 & 1 & 0 & 0 & 0 & 4 & 0 & 12 & 4 & 0 & 10 & 0 & 0 \\
\hline $\mathrm{Ce}$ & 24 & 27 & 3 & 21 & 11 & 15 & 45 & 31 & 36 & 15 & 33 & 20 & 19 & 5 & 17 \\
\hline $\mathrm{Th}$ & 1 & 2 & 0 & 0 & 2 & 0 & 1 & 1 & 0 & 1 & 1 & 2 & 2 & 0 & 0 \\
\hline Strat, m & 6,415 & 6,025 & 6,020 & 6,015 & 5,315 & 4,800 & 4,370 & 4,245 & 4,080 & 3,445 & 3,385 & 3,385 & 1,385 & 215 & 130 \\
\hline Type & pf & $\mathrm{si} / \mathrm{sh}$ & $\mathrm{si} / \mathrm{sh}$ & $\mathrm{pf}$ & pf & $\mathrm{si} / \mathrm{sh}$ & pf & pf & $\mathrm{pf}$ & $\mathrm{si} / \mathrm{sh}$ & $\mathrm{pf}$ & $\mathrm{pf}$ & $\mathrm{pf}$ & $\mathrm{pf}$ & $\mathrm{pf}$ \\
\hline
\end{tabular}

See text for details of analyses; nd means not determined; 0 means below detection limit. Abbreviations for type of sample are: $\mathrm{cf}=$ columnar flow; $\mathrm{pb}=$ pillowed basalt; $\mathrm{pf}=$ polygonal flow, $\mathrm{si} / \mathrm{sh}=$ massive sill or sheetflow. 
Sediments interbedded with the uppermost Crescent flows at Pulali Point contain a Ulatisian to lower Narizian faunal assemblage that corresponds to an age of about $48 \mathrm{Ma}$ (Rau, personal communication, 1990).

\section{GEOCHEMISTRY}

Table 2 presents analyses for 63 samples collected at intervals through the entire vertical section represented by the DCVS. Elevations given in Table 2 are referenced to a base marked by continuous exposure (as opposed to interbeds) of the underlying Blue Mountain unit. Analyses were carried out on an automated $\mathrm{X}$ ray fluorescence spectrometer in the laboratory of $P$. Hooper at Washington State University. For basalt analyses the relative standard deviations of major and minor element analyses were less than $0.5 \%$, except for $\mathrm{Na}$, which was $0.65 \%$. The trace elements have high precision and accuracy down to 1-3 ppm, except for $\mathrm{Ni}, \mathrm{Cr}, \mathrm{Sc}, \mathrm{V}$, and $\mathrm{Ba}$, which must be regarded as semiquantitative below about 30 ppm. $\mathrm{Nb}$ and $\mathrm{Y}$ could probably be measured to 0.1 ppm.

Glassley [1974; Glassley et al., 1976] argued that differences in $\mathrm{TiO}_{2}, \mathrm{FeO} / \mathrm{MgO}$, and rare earth element content could be used to distinguish tectonically juxtaposed upper and lower basalt members of the Crescent Formation. However, Cady [1975] and Lyttle and Clarke [1975] cited their geochemical data as evidence for a continuously evolving volcanic sequence, with gradational rather than abrupt changes in composition between the lower and upper parts. Our data show that there is indeed a distinct difference in chemistry between the upper and lower Crescent basalts. A diagnostic pattern of geochemical variation as a function of stratigraphic position is shown by

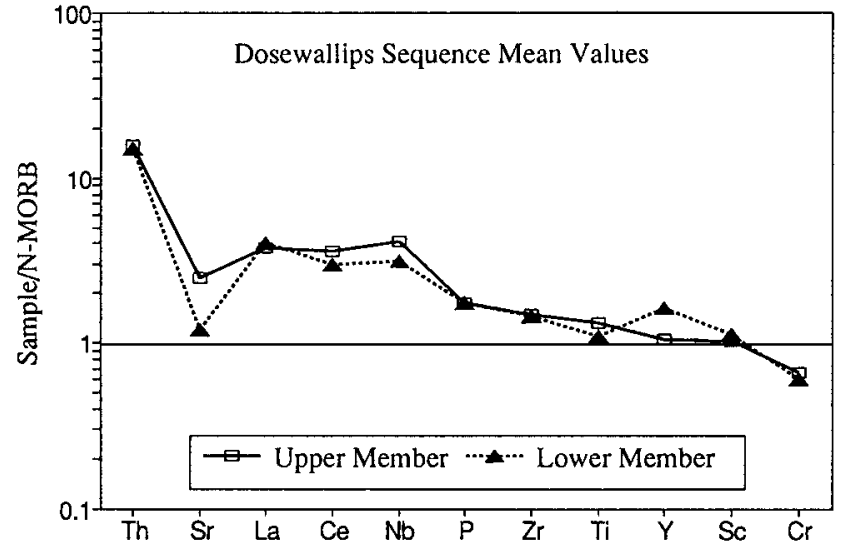

Fig. 4. Variation in $\mathrm{Zr} / \mathrm{Y}$ with position in the Dosewallips composite volcanic sequence. Thickness is measured as the vertical distance (corrected for attitude of bedding) above the contact between Crescent volcanics and the underlying Blue Mountain unit (BMu). Notice that the boundary between the upper and lower chemical types may be somewhat below the boundary between the subaerial and submarine basalts shown on the diagram.

Figure 4. The basalts constituting an upper chemical type (UCT) are clearly shifted towards higher $\mathrm{Zr} / \mathrm{Y}$ ratios compared to basalts of the lower chemical type (LCT). Note that the break between the LCT and the UCT appears to be located just below the "stratigraphic" boundary between the upper and lower members of the Crescent basalt as mapped by Tabor and Cady [1978], that is, some of the submarine basalts show the same enriched chemistry as the overlying subaerial flows. Similar "up sequence" changes are displayed by other ratios indicative of source composition (for example, $\mathrm{Zr} / \mathrm{Nb}, \mathrm{Y} / \mathrm{Nb}, \mathrm{Ti} / \mathrm{V}$, and $\mathrm{Ce} / \mathrm{Y}$ ). Mean values in Table 3 show that the $\mathrm{SiO}_{2}$,

TABLE 3a. Means and Standard Deviations of Major and Minor Element Compositions of Upper and Lower Crescent Basalts

\begin{tabular}{llllll}
\hline & $\begin{array}{l}\text { Dosewallips } \\
\text { Lower Crescent }\end{array}$ & $\begin{array}{l}\text { Dosewallips } \\
\text { Upper Crescent }\end{array}$ & $\begin{array}{l}\text { Glassley } \\
\text { Lower Crescent }\end{array}$ & $\begin{array}{l}\text { Glassley }{ }^{1} \\
\text { Upper Crescent }\end{array}$ & $\begin{array}{l}\text { Glassley }^{1} \\
\text { Intrusives }\end{array}$ \\
\hline$n$ & 24 & 38 & 19 & 9 & 7 \\
$\mathrm{SiO}_{2}$ & $49.00 \pm 0.59$ & $49.09 \pm 0.21$ & $49.94 \pm 0.41$ & $50.62 \pm 0.65$ & $49.37 \pm 0.51$ \\
$\mathrm{TiO}_{2}$ & $1.63 \pm 0.10$ & $2.00 \pm 0.05$ & $1.59 \pm 0.09$ & $2.29 \pm 0.28$ & $2.86 \pm 0.32$ \\
$\mathrm{Al} 2 \mathrm{O}_{3}$ & $14.12 \pm 0.23$ & $14.54 \pm 0.18$ & $15.47 \pm 0.50$ & $14.39 \pm 0.48$ & $14.26 \pm 0.53$ \\
$\mathrm{FeOT}$ & $12.44 \pm 0.52$ & $11.35 \pm 0.20$ & $10.23 \pm 0.68$ & $9.26 \pm 1.22$ & $11.97 \pm 0.53$ \\
$\mathrm{MnO}$ & $0.22 \pm 0.01$ & $0.21 \pm 0.01$ & $0.26 \pm 0.03$ & $0.31 \pm 0.04$ & $0.33 \pm 0.03$ \\
$\mathrm{MgO}$ & $6.99 \pm 0.44$ & $6.78 \pm 0.14$ & $7.39 \pm 0.34$ & $7.43 \pm 0.59$ & $5.71 \pm 0.30$ \\
$\mathrm{CaO}$ & $8.87 \pm 0.43$ & $10.78 \pm 0.17$ & $11.29 \pm 0.35$ & $10.74 \pm 0.56$ & $10.26 \pm 0.40$ \\
$\mathrm{Na} 2 \mathrm{O}$ & $3.21 \pm 0.22$ & $3.21 \pm 0.09$ & $2.96 \pm 0.15$ & $3.28 \pm 0.16$ & $3.64 \pm 0.16$ \\
$\mathrm{~K} 2 \mathrm{O}$ & $0.59 \pm 0.14$ & $0.27 \pm 0.04$ & $0.47 \pm 0.10$ & $0.29 \pm 0.06$ & $0.66 \pm 0.14$ \\
$\mathrm{P} 2 \mathrm{O} 5$ & $0.21 \pm 0.04$ & $0.21 \pm 0.01$ & $0.13 \pm 0.02$ & $0.16 \pm 0.04$ & $0.26 \pm 0.04$ \\
$\mathrm{Mg} \mathrm{Number}$ & $49.3 \pm 2.4$ & $51.6 \pm 0.8$ & $56.6 \pm 2.3$ & $59.4 \pm 4.6$ & $46.6 \pm 1.6$ \\
\hline
\end{tabular}

$\mathrm{Mg}$ Number is $\mathrm{mol} \% \mathrm{MgO} / \mathrm{MgO}+\mathrm{FeO}$ total

1 Values are from Glassley [1974]. 
TABLE 3b. Means and Standard Deviations of Trace Element Composition of Upper and Lower Crescent Basalts

\begin{tabular}{|c|c|c|c|c|c|}
\hline & Lower Crescent ${ }^{1}$ & Upper Crescent $^{1}$ & N-MORB ${ }^{2}$ & E-MORB ${ }^{2}$ & $\mathrm{O}^{2} \mathrm{~B}^{2}$ \\
\hline $\mathbf{S r}$ & $145 \pm 12$ & $291 \pm 22$ & 90 & 155 & 660 \\
\hline $\mathbf{R b}$ & $12.8 \pm 3.4$ & $3.4 \pm 0.5$ & 0.6 & 5.0 & 31 \\
\hline $\mathrm{Ba}$ & $56 \pm 20$ & $46 \pm 7$ & 6.3 & 57 & 350 \\
\hline $\mathbf{N b}$ & $11.0 \pm 1.8$ & $14.4 \pm 0.6$ & 2.3 & 8.3 & 48 \\
\hline $\mathrm{Zr}$ & $132 \pm 21$ & $132 \pm 5$ & 74 & 73 & 280 \\
\hline $\mathbf{Y}$ & $49 \pm 7$ & $32 \pm 1$ & 28 & 22 & 29 \\
\hline Sc & $45 \pm 2$ & $41 \pm 1$ & - & - & - \\
\hline $\mathbf{V}$ & $328 \pm 2.5$ & $330 \pm 6$ & - & - & - \\
\hline $\mathrm{Ga}$ & $17 \pm 1$ & $18 \pm 1$ & - & - & -- \\
\hline $\mathrm{Cu}$ & $134 \pm 11$ & $153 \pm 11$ & - & - & - \\
\hline $\mathrm{Cr}$ & $149 \pm 23$ & $165 \pm 13$ & - & -- & - \\
\hline $\mathrm{Ni}$ & $63 \pm 8$ & $63 \pm 4$ & - & - & - \\
\hline La & $4.6 \pm 1.1$ & $11.5 \pm 2.9$ & 2.5 & 6.3 & 37 \\
\hline $\mathrm{Ce}$ & $10.9 \pm 2.6$ & $31 \pm 6$ & 7.5 & 15 & 80 \\
\hline Nd & $10.5 \pm 1.5$ & $21 \pm 6$ & 7.3 & 9 & 39 \\
\hline $\mathrm{Sm}$ & $3.9 \pm 0.3$ & $5.5 \pm 1.0$ & 2.6 & 2.6 & 10 \\
\hline $\mathrm{Eu}$ & $1.1 \pm 0.1$ & $1.5 \pm 0.2$ & 1.0 & 0.9 & 3.0 \\
\hline $\mathrm{Tb}$ & $0.7 \pm 0.3$ & $0.6 \pm 0.04$ & 0.7 & 0.5 & 1.1 \\
\hline$Y b$ & $2.9 \pm 0.2$ & $2.7 \pm 0.3$ & 3.1 & 2.3 & 2.2 \\
\hline $\mathbf{L u}$ & $0.6 \pm 0.1$ & $0.5 \pm 0.06$ & 0.5 & 0.4 & 0.3 \\
\hline $\mathrm{Zr} / \mathrm{Y}$ & $2.7 \pm 0.1$ & $4.3 \pm 0.1$ & 2.6 & 3.3 & 9.7 \\
\hline $\mathrm{Zr} / \mathrm{Nb}$ & $13.0 \pm 0.6$ & $9.3 \pm 0.2$ & 32 & 8.7 & 5.8 \\
\hline $\mathrm{Y} / \mathrm{Nb}$ & $5.2 \pm 0.4$ & $2.2 \pm 0.1$ & 12.2 & 2.7 & 0.6 \\
\hline $\mathrm{La} / \mathrm{Sm}$ & $0.9 \pm 0.1$ & $1.5 \pm 0.2$ & 1.0 & 24 & 3.7 \\
\hline $\mathrm{La} / \mathrm{Yb}$ & $1.6 \pm 0.4$ & $3.7 \pm 0.7$ & 0.8 & 2.7 & 16.8 \\
\hline
\end{tabular}

1 Rare earth element values are from Glassley [1974].

2 Values are from Sun and McDonough [1989].

$\mathrm{Al}_{2} \mathrm{O}_{3}, \mathrm{MgO}, \mathrm{Mg}$ number (mde percent $\mathrm{MgO} / \mathrm{MgO}+$ $\mathrm{FeO}$ total), and magmatophile element contents of the UCT are similar to the LCT. However the $\mathrm{TiO}_{2}, \mathrm{Sr}$, $\mathrm{Nb}, \mathrm{Zr} / \mathrm{Y}, \mathrm{La} / \mathrm{Sm}$, and $\mathrm{La} / \mathrm{Yb}$ ratios of the $\mathrm{LCT}$ are significantly lower than the UCT, while $\mathrm{Rb}, \mathrm{Y}, \mathrm{Zr} / \mathrm{Nb}$, and $\mathrm{Y} / \mathrm{Nb}$ are significantly higher. Note also that dikes

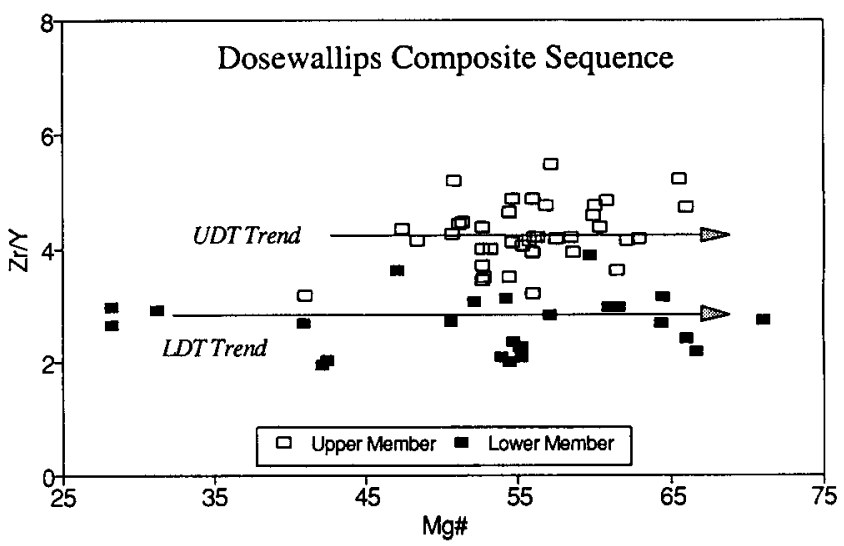

Fig. 5. Spidergram comparing mean values of upper and lower Crescent basalt. Normalized to N-MORB values of Pearce [1984] and Sun and McDonough [1989]. in the LCT analyzed by Glassley [1974] resemble UCT flows and may be feeders for the upper part of the sequence. The difference between the UCT and the LCT is shown in the spidergram of Figure 5, which also indicates that both are generally enriched by a factor of 2 to 10 in magmatophile elements when compared with normal $(\mathrm{N})$ MORB values. $\mathrm{Rb}, \mathrm{Ba}$, and $\mathrm{K}$ values are not shown because they have clearly been mobilized by the low-grade metamorphism that effects the Crescent basalts. Strontium values also are suspect but have been plotted because they are relatively consistent.

In general, UCT flows are slightly more fractionated than the LCT flows, but this cannot explain the difference in chemistry. As shown by Figure 6 there is no correlation between $\mathrm{Mg}$ number and $\mathrm{Zr} / \mathrm{Y}$ ratios. (The same applies to $\mathrm{Zr} / \mathrm{Nb}, \mathrm{Y} / \mathrm{Nb}$, and $\mathrm{Ce} / \mathrm{Y}$ ratios.) This is not surprising because $\mathrm{Zr}, \mathrm{Nb}$, and $\mathrm{Y}$ are all highly incompatible elements with similar distribution coefficients in basaltic magmas, and thus their ratios should be relatively insensitive to the effects of crystal fractionation. These elements can be differentiated somewhat by variable percentages of partial melting with residual garnet and clinopyroxene. However, variations in $\mathrm{Y} / \mathrm{Nb}$ and $\mathrm{Zr} / \mathrm{Nb}$ ratios of the magnitude 


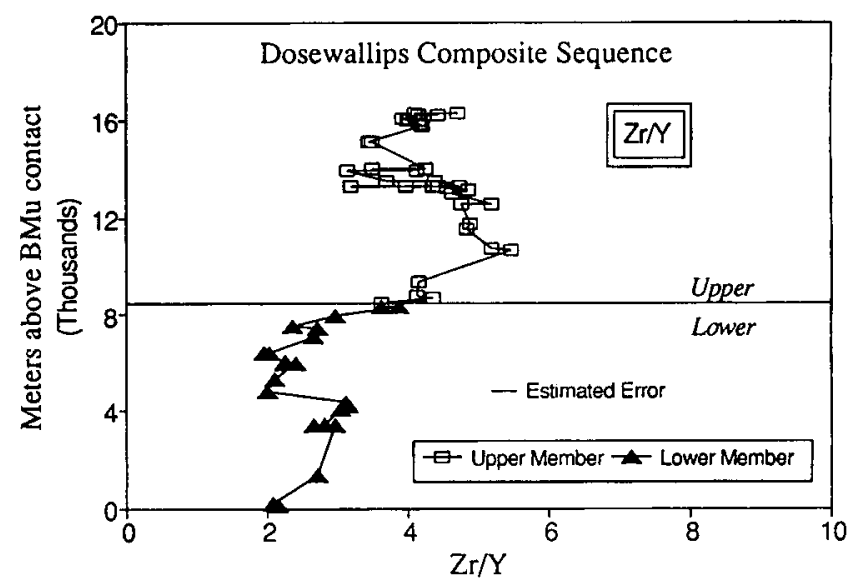

Fig. 6. $\mathrm{Zr} / \mathrm{Y}$ versus $\mathrm{Mg}$ number. $\mathrm{Mg}$ number is defined as molecular ratio of $\mathrm{MgO} / \mathrm{MgO}+$ total $\mathrm{Fe}$ as $\mathrm{FeO}$. The upper and lower chemical types show a similar degree of differentiation, but two different trends of $\mathrm{Zr} / \mathrm{Y}$ variation.

displayed by the Crescent basalts (Figure 7) are presumed to reflect source heterogeneities [Le Roex et al., 1983]. Most Crescent data fall along a mixing array between oceanic island basalt (OIB)-like and $\mathrm{N}$ MORB-like mantle reservoirs [LeRoex et al., 1983]. The UCT basalts appear to have a source similar to enriched $(E)$ and plume influenced (P)-type MORBs, while the LCT basalts range from $\mathrm{E}$ - to $\mathrm{N}$-type, with the exception of a distinctive group of three P-type samples (petrography shows that these contain greenschist facies assemblages).

\section{PALEOMAGNETISM}

Data from the subaerial Crescent flows sampled in the vicinity of Mount Walker and Port Ludlow (Figure 2) are summarized in Table 4. Samples from most sites showed demagnetization paths trending towards the origin after removal of a small overprint in the first step or two. Figure 8 shows typical demagnetization diagrams from a normally magnetized site near Mount

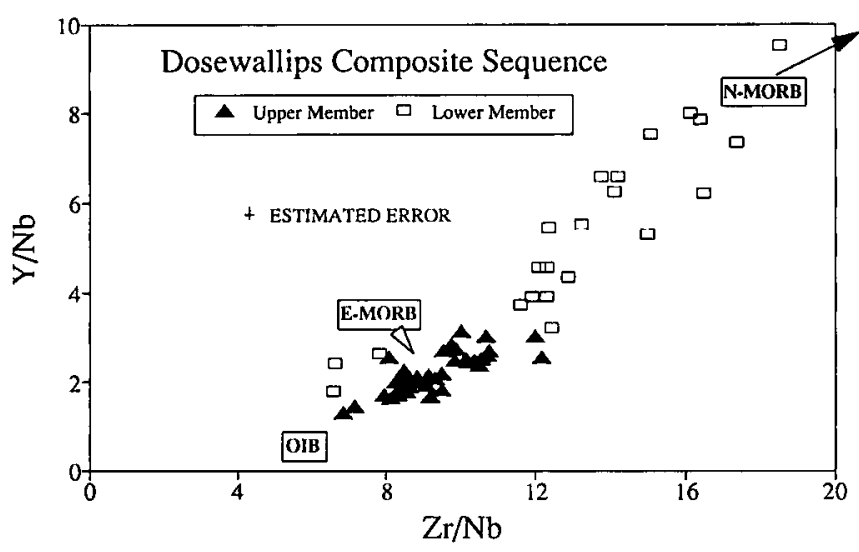

Fig. 7. $\mathrm{Y} / \mathrm{Nb}$ versus $\mathrm{Zr} / \mathrm{Nb}$. OIB, E-MORB, and $\mathrm{N}-\mathrm{MORB}(\mathrm{Zr} / \mathrm{Nb}$ $=31 ; \mathrm{Nb} / \mathrm{Y}=12$ ) are from Sun and McDonough [1989].
Walker and a reversely magnetized site near Port Ludlow. Both sites shows similar demagnetization behavior despite having different directions. Most of the remanence resides in magnetite, as shown by a decay of $70-80 \%$ by $100 \mathrm{mT}$ or $580^{\circ} \mathrm{C}$. Demagnetization above $580^{\circ} \mathrm{C}$ continues the demagnetization path along the same trend, indicating that a small but important part of the apparently single-component remanence resides in hematite. Magnetic moment per unit volume also is similar and reasonably high, typically $2 \mathrm{Am}^{-1}$ for most sites. A few samples were excluded from calculation of mean directions owing to poor signal-tonoise ratios or poor linearity of demagnetization paths.

Several observations indicate that magnetization in the Mount Walker section dates from extrusion of the lavas. First, relatively strong and single-component magnetizations are carried by both magnetite and hematite (Figure 8). Second, two polarities are recorded. The occurrence of reversely magnetized site (mw01) in the middle of the Mount Walker section is difficult to explain by remagnetization; the mechanism would have to be quite localized yet pervasive enough to affect both magnetic minerals. Third, many of the site mean directions are distinct as expected of flows magnetized instantaneously at different times during secular variation of the paleomagnetic field. The only contrary indication is that correction of individual flows to paleohorizontal scatters the directions slightly (note insignificantly increased $k$, Table $4 b$ ). However, this does not require the magnetizations to be post folding. The increased scatter more likely results from small errors in measured attitudes and/or some slight variation in original dip.

Magnetizations from the Port Ludlow sites have intensities comparable to the Mount Walker section and also appear to be single component, carried by both magnetite and hematite. New results from Port Ludlow, supplemented by previous results from Port Townsend [Warnock, 1989], become slightly less scattered upon correction (increased $k$, Table $4 b$ ).

The similarity of magnetic characteristics and field relationships indicate that the basalt flows at Mount Walker and Port Ludlow could have a common origin. If this is true, then a fold test on the combined data set is valid. One caution is that the Discovery Bay fault zone (Figure 2) runs between the two localities. This fault has been interpreted by MacCloud et al. [1977] as a terrane boundary; however, gravity modelling indicates that it is probably within the Crescent Formation and that the true terrane boundary lies to the east in the Puget Sound [Roberts, 1991]. Accepting Robert's interpretation, we have tested the combined data set (Table $4 b$; Figure 9). Upon correction, the dispersion of directions from the two areas and their mean directions become similar, which is consistent with both data sets having sampled the same paleomagnetic field despite the uneven distribution of 
TABLE 4a. Site Mean and Locality Mean Directions and Statistics

\begin{tabular}{|c|c|c|c|c|c|c|c|c|c|c|c|c|}
\hline Site & Dec-u & Inc-u & Dec-c & Inc-c & $R$ & $N$ & $a-95$ & $A z$ & Dip & Lo & $\mathbf{H i}$ & Ty \\
\hline $\mathrm{mw03}$ & 315.2 & +17.2 & 321.4 & +60.0 & 5.977 & 6 & 4.6 & 128 & 43 & 35 & 100 & $\mathbf{t}$ \\
\hline mw10 & 328.5 & +36.6 & 11.5 & +70.2 & 5.990 & 6 & 2.9 & 128 & 43 & 30 & 100 & $\mathbf{a}$ \\
\hline mw02 & 319.0 & +22.1 & 336.0 & +58.5 & 5.974 & 6 & 4.9 & 119 & 40 & 35 & 100 & $t$ \\
\hline mw08 & 300.9 & +46.1 & 283.6 & +87.8 & 3.993 & 4 & 4.4 & 122 & 42 & 40 & 40 & $t$ \\
\hline $\mathrm{mw01}$ & 143.5 & -30.7 & 173.0 & -66.0 & 5.981 & 6 & 4.2 & 122 & 42 & 20 & 1000 & $\mathbf{a}$ \\
\hline mw07 & 324.5 & +54.0 & 77.6 & +74.5 & 4.987 & 5 & 4.3 & 25 & 45 & 30 & 100 & $\mathbf{a}$ \\
\hline mw06 & 293.9 & +27.9 & 273.9 & 70.8 & 6.981 & 7 & 3.4 & 125 & 45 & 20 & 60 & $\mathbf{t}$ \\
\hline mw0s & 326.6 & +26.9 & 351.7 & +67.2 & 6.943 & 7 & 5.9 & 130 & 45 & 30 & 70 & $\mathbf{a}$ \\
\hline mw04 & 320.0 & +34.2 & 348.6 & +76.4 & 5.979 & 6 & 4.4 & 130 & 45 & 30 & 70 & $\mathbf{t}$ \\
\hline $\mathrm{p} 101$ & 165.5 & -67.3 & 132.3 & -41.0 & 8.949 & 9 & 4.1 & 286 & 34 & 20 & 100 & $\mathbf{t}$ \\
\hline $\mathrm{pl03}$ & 140.3 & -74.3 & 155.8 & -42.3 & 5.971 & 6 & 5.1 & 344 & 33 & 30 & 100 & $t$ \\
\hline pt01 & 175.7 & -59.4 & 189.7 & -52.0 & 6.930 & 7 & 6.6 & 55 & 2 & 20 & 20 & $a$ \\
\hline pt02 & 182.5 & -46.0 & 190.6 & -55.9 & 5.964 & 6 & 5.7 & 55 & 2 & 20 & 20 & $\mathbf{a}$ \\
\hline pt03 & 45.0 & -58.7 & 126.9 & -76.1 & 5.964 & 6 & 5.7 & 19 & 33 & 10 & 10 & $\mathbf{a}$ \\
\hline pt04 & 7.0 & -61.0 & 251.0 & -82.7 & 4.980 & 5 & 5.5 & 19 & 33 & 20 & 20 & $\mathbf{a}$ \\
\hline pt05 & 65.9 & -60.3 & 138.0 & -63.5 & 5.991 & 6 & 2.9 & 16 & 35 & 10 & 10 & $\mathbf{a}$ \\
\hline pt06 & 65.2 & -57.4 & 103.9 & -55.3 & 5.909 & 6 & 9.1 & 350 & 25 & 10 & 10 & $\mathbf{a}$ \\
\hline $\mathrm{pt} 07$ & 265.1 & -60.0 & 253.0 & -68.1 & 7.954 & 8 & 4.5 & 295 & 10 & 30 & 30 & $\mathbf{a}$ \\
\hline $\mathrm{pt} 08$ & 143.7 & -83.8 & 125.7 & -64.2 & 2.620 & 9 & 4.5 & 300 & 20 & 10 & 10 & $\mathbf{a}$ \\
\hline pt09 & 29.6 & -56.3 & 89.6 & -74.1 & 7.895 & 8 & 6.8 & 0 & 30 & 10 & 10 & $\mathbf{a}$ \\
\hline
\end{tabular}

Site: mw from Mount Walker (western) section in stratigraphic order, pl from Port Ludiow, pt from Port Townsend (data recalculated from Beck and Engebretson [1982]; Dec-u, Inc-u, Dec-c and Inc-c are site mean declination and inclination uncorrected $(-u)$ and corrected (-c) for dip tilt in downdip azimuth (Az) direction; $R$ is resultant of $N$ unit vectors in sample directions; $a-95$ is semi-angle of cone of $95 \%$ confidence about the mean. Lo and $\mathrm{Hi}$ indicate the range in milliteslas) of alternating fieid demagnetization ( $\mathrm{Ty}=\mathrm{a}$ ) used to obtain sample directions; where Ty is $t$, directions from thermal pilots are included (typical range $400^{\circ}-630^{\circ} \mathrm{C}$ ).

polarities. Convergence of site mean directions and a significant increase in the precision parameter upon correction suggest that the magnetizations were more likely acquired before deformation than after. Given the nearly complete partitioning of polarities between areas, lack of significant difference in corrected directions serves as a positive reversal test as well. This and dispersion typical of secular variation [McFadden and McElhinny, 1984] support complete sampling of the dipole field and also contradict Glassley's [1974] contention that the upper and lower sections of the Crescent were coeval and later faulted into juxtaposition.

The mean of the corrected site mean directions

TABLE 4b. Site Mean and Locality Mean Directions and Statistics Corrected for Tilt

\begin{tabular}{llccccccccc}
\hline & Dec-u & Inc-u & Dec-c & Inc-c & $R$ & $N$ & $a-95$ & $k$ & $k / k$ & Fc \\
\hline Mn-m & 316.9 & +33.3 & & & 8.72 & 9 & 9.8 & 28.78 & & \\
Mn-m & & & 305.8 & +77.0 & 8.55 & 9 & 12.6 & 17.62 & 1.63 & 2.33 \\
Mn-p & 275.9 & +81.2 & & & 9.71 & 11 & 17.5 & 7.71 & & \\
Mn-p & & & 321.7 & +67.7 & 10.31 & 11 & 12.4 & 14.49 & 1.86 & 2.12 \\
Mean & 310.3 & +59.5 & & & 16.70 & 20 & 14.9 & 5.75 & & \\
Mean & & & 316.5 & +72.1 & 18.78 & 20 & 8.6 & 15.57 & 2.70 & 1.72 \\
Expt & 349.6 & +67.4 & 349.6 & +67.4 & & & & & & \\
\hline
\end{tabular}

Here $k$ is precision parameter [Fisher, 1953]. If the ratio of $k$ s before and after untilting $(k / k)$ exceeds the $F$ statistic for $2(N$ 1) $\times 2(N-1)$ degrees of freedom $(F c)$, there is significant change in the dispersion upon tilt correction [McElhinny, 1964]. $\mathrm{Mn}-\mathrm{m}, \mathrm{Mn}-\mathrm{p}$, and Mean are means of the western and eastern sections and all sites. Expt is direction expected for mean location $47.9^{\circ} \mathrm{N}, 237.2^{\circ} \mathrm{E}$ calculated from 54-44 Ma pole of Diehl et al. [1983]. See Table 4a for other information. 

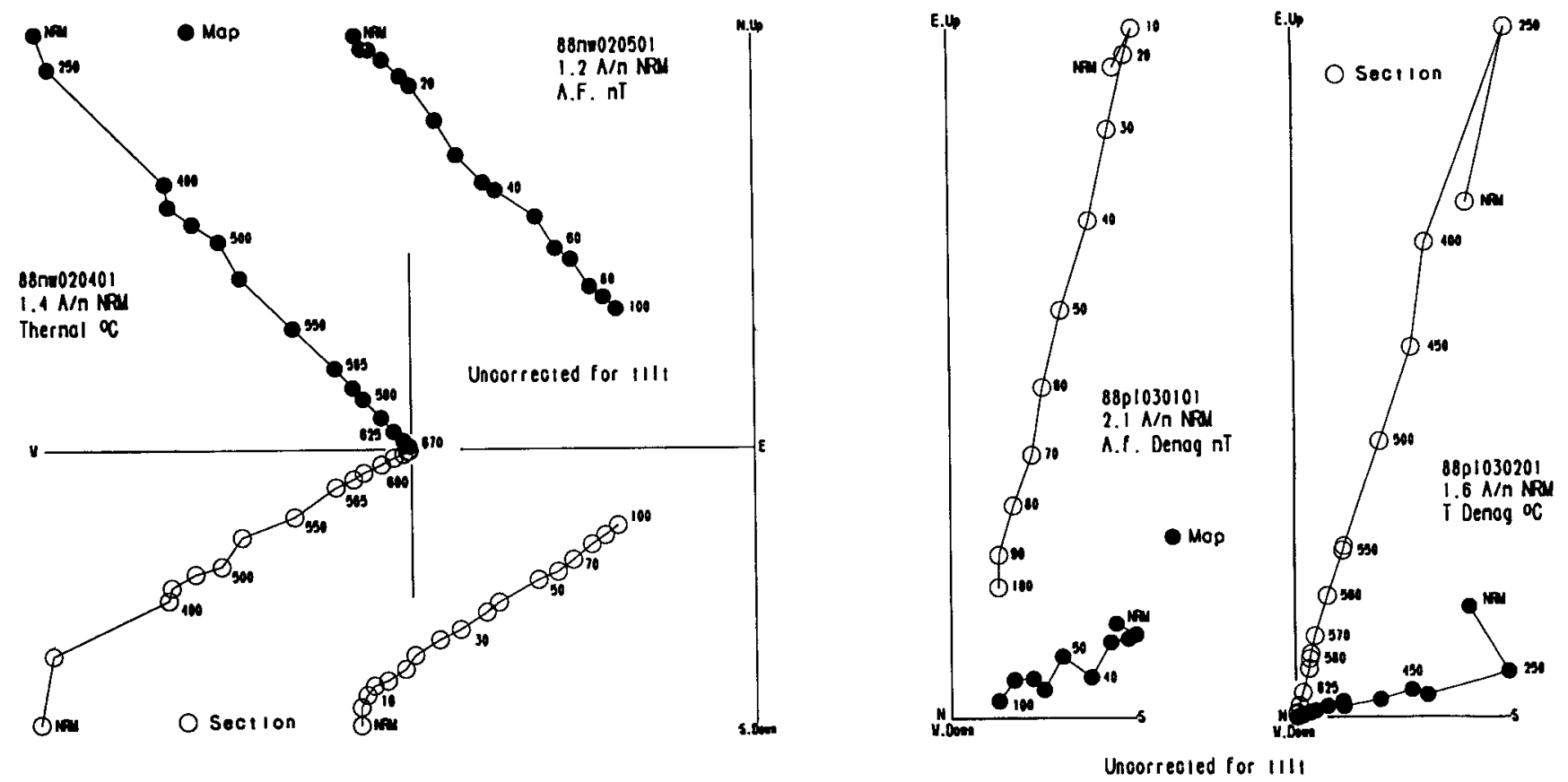

Fig. 8. Orthogonal projections of demagnetization paths for two pairs of adjacent samples typical of the subareal flows west (left pair) and east of the Discovery Bay fault. Initial intensities are comparably strong ( $>1 \mathrm{Am}^{-1}$ moment per unit volume or $10^{-3}$ emu intensity), and paths for both sites are similar in unblocking temperature spectra that show both magnetite and hematite retain the same component of magnetization. The difference between sites is that most rocks west of the Discovery Bay fault are magnetized NW and downward, whereas all those to the east are magnetized SSE and up.

(Table $4 b)$ is neither significantly counterclockwise $(R$ $=13.0 \pm 26.0)$ of the direction expected for this area in the Eocene nor different in inclination $(F=4.7 \pm 8.9)$. The conclusions are (1) these rocks have experienced insignificant poleward motion since formation and (2) subsequent deformation can be modeled as simple tilt about local horizontal axes with negligible vertical axis rotation. In other words, the northern part of the Crescent Formation has experienced only simple folding or fault block tilting, with no discernible northward translation or rotation.

\section{PALEOTECTONICS}

On a regional scale, there is little doubt that the major tectonic interaction near the Coast Ranges during early to mid Tertiary time was subduction of oceanic lithosphere beneath North America. Frequent changes in the direction and speed of relative motion in this region were caused both by changes in plate velocity and by migration of plate boundaries. These would have resulted in the juxtaposition of different plates with North America (triple junction passages). Subduction of other bathymetric features such as fracture zones and seamounts also may have had an impact. Moreover, the age of the subducting plates must have changed markedly with the approach to the margin of active ridges. Of equal importance is the possibility of plate fragmentation. Recent breakup of the Juan de Fuca plate as it enters the Cascadia subduction zone offers a present-day analogy. Figure 10 shows in a general way the major plates that probably interacted during the Eocene in the Pacific Northwest; a brief description of the kinematics of each plate follows. Relative velocities and reconstruction parameters used by Engebretson et al. [1985] have been updated using the new magnetic time scale of Kent and Gradstein [1985] and the revised Africa-North American motions of Klitgord and Schouten [1986].

\section{North America}

Throughout the Tertiary, North America moved over the mantle hotspot reference frame in a general westerly direction. During the interval.68-63 Ma there was a distinct change in the vector of relative motion between North America and the hotspots (Figure 11b). A decrease in the component of hotspot velocity perpendicular to the coastline from greater than 40 $\mathrm{km} / \mathrm{m}$.y. to less than $25 \mathrm{~km} / \mathrm{m}$.y. also is inferred at approximately $50 \mathrm{Ma}$ (Figure 11e). Because extension behind active arcs occurs when upper plate velocities are slow or directed away from the subduction zone, it is possible that this change was related to the development of an overall extensional regime in western North America. 


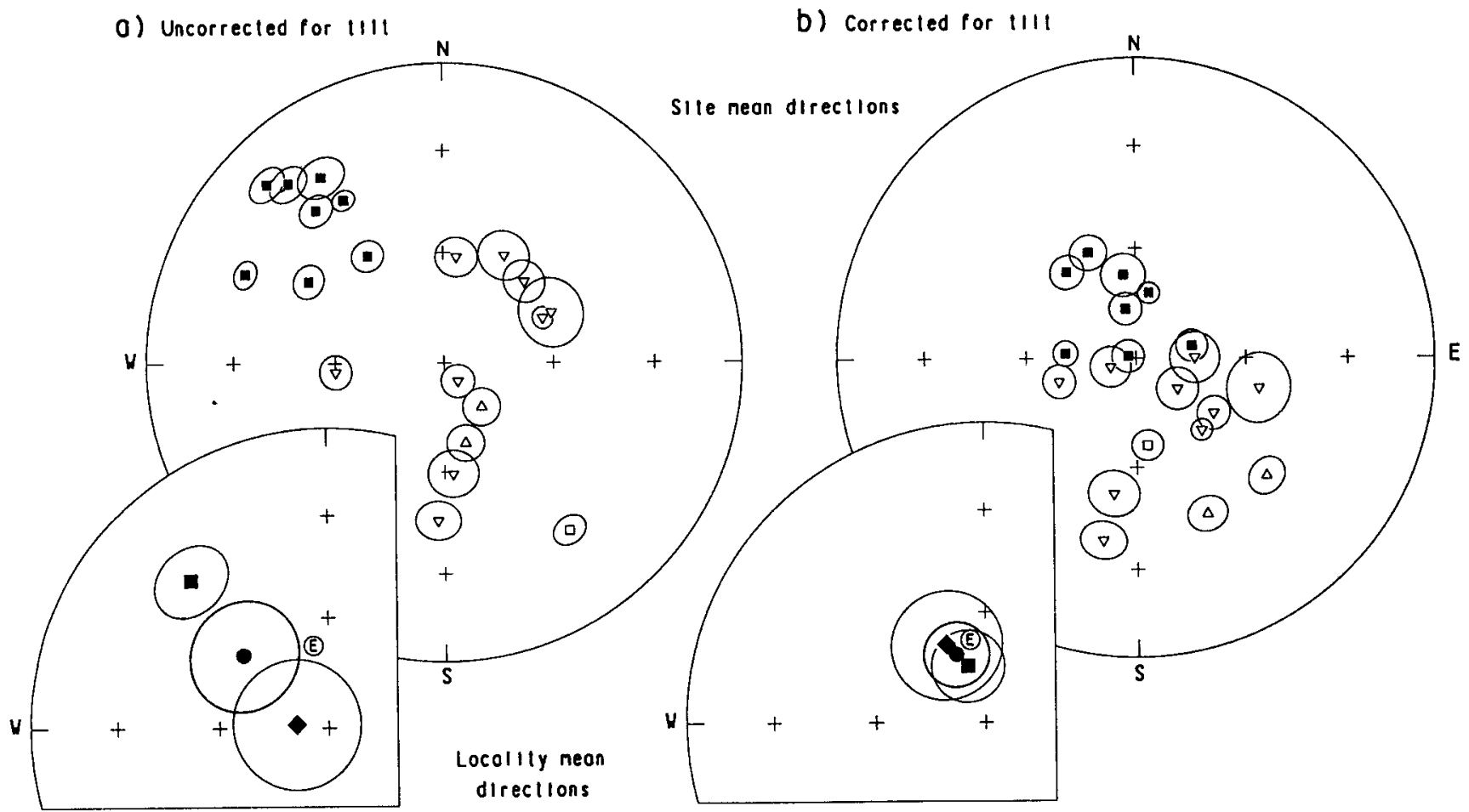

Fig. 9. Equal-area projections of mean directions (Table 4) before tilt correction (on the left) and after (on the right). Solid (open) symbols indicate downward (upward) directions. Squares, triangles, and inverted triangles in the upper circle are mean directions from Mount Walker, Port Ludlow, and Port Townsend sites, respectively. Quadrant inserts below show mean direction of sites (reverse polarities inverted) from Mount Walker (square), Port Ludlow (plus) Port Townsend (diamond), and all sites combined (circle) in comparison with the Eocene expected direction (circled E). Ovals are 95\% confidence limits. Correction for tilt reduces the scatter of the combined data set (positive fold test) and makes the site mean directions from the mostly normally magnetized western rocks coincide with the mean directions from the reversely magnetized eastern sites (positive reversal test).

\section{Pacific}

Initial Pacific-North America interaction near Cascadia probably occurred after the formation of the Coast Ranges. However, there remains the possibility that the Kula plate fused to the Pacific plate as early as about $52 \mathrm{Ma}$, which would have resulted in PacificNorth America interaction at this time. Pacific plate motion relative to North America between 55 and 43 $\mathrm{Ma}$ would have been quite similar to that of the Farallon plate. The Pacific-Farallon-North America triple junction in this scenario probably would have been dominated by transforms, given the implied slow divergence on the intervening Pacific-Farallon ridge and the inferred northeasterly trend of that boundary. An abrupt counterclockwise rotation of Pacific-North America linear velocity vector at about $42 \mathrm{Ma}$ is reflected in the bend of the Hawaiian-Emperor hotspot track. Synchronous with this important tectonic event is a distinct decrease in the rate of Farallon and Pacific convergence (Figure 11f) accompanied by the transition to less severe tectonism throughout the Pacific Northwest.

\section{Farallon}

Throughout most of the Late Cretaceous and the entire Tertiary, the Farallon plate diminished in size and average crustal age as it was consumed beneath western North America trenches. This was accompanied by the approach of the Pacific-Farallon ridge, northward migration of the Kula-Farallon-North America triple junction, segmentation and breakup of the Farallon plate, and continual readjustments in linear velocities. An obvious feature of the Farallon velocities seen in Figure 11 is the general velocity decrease after $59 \mathrm{Ma}$, presumably in response to the younger and hence more buoyant plate entering the trench. Also notable is the observed consistent northeasterly directed convergence implying continuing oblique subduction beneath North America. A big decrease in convergence velocity can be seen at about $50 \mathrm{Ma}$ (Figure 11e).

\section{Kula}

As modeled by Engebretson et al. [1984, 1985] and Stock and Molnar' [1988], the Kula plate broke away 


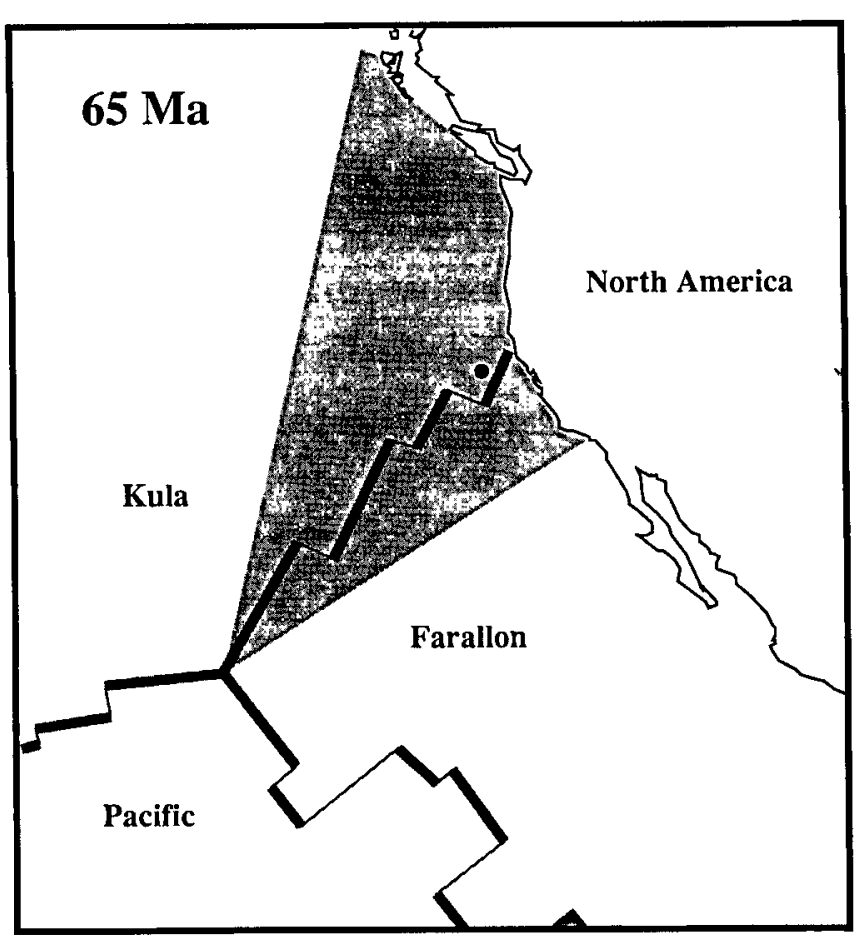

Fig. 10. Plate tectonic scenario for the western margin of North America at $65 \mathrm{Ma}$ based on reconstructions in fixed hotspot reference frame. Shading shows the uncertainty of the position of the Kula-Farallon-North America triple junction based on propagated errors. The uncertainty in the position of the Yellowstone hotspot (YHS) is comparable to that of the triple junction.

from an ancestral Farallon plate in the Late Cretaceous (about $85 \mathrm{Ma}$ ) and moved in a more northerly direction; it subsequently became part of the Pacific plate. The time of the demise of the Pacific-Kula ridge remains uncertain, but estimates range from about 60 Ma [Byrne, 1979] to $43 \mathrm{Ma}$ [Engebretson et al., 1984; Lonsdale, 1988]. Models for the post early Eocene tectonics in the Pacific Northwest are significantly different with and without a Kula plate because the implied relative velocities would have been so different. Kula-North America velocities would have been more oblique (right lateral) and generally faster. Moreover, triple junction kinematics would have induced vastly different tectonic regimes as discussed below. Of particular interest here is the marked increase of both the normal and tangential velocities of the Kula plate relative to North America at about $59 \mathrm{Ma}$ and the distinct decrease after about $50 \mathrm{Ma}$ (Figures $11 \mathrm{~d}$ and $11 e)$.

\section{Boundaries Between Plates}

Development of a viable plate tectonic model for the origin and evolution of the Cordillera depends on knowing the location through time of the boundaries between the plates. Local instantaneous linear velocities can be used to infer the migration and style of triple junctions, but many options and uncertainties exist. The probable existence of ridge offsets along the Kula-Farallon ridge system means that the triple junction could have jumped to new locations quite frequently. This would have resulted in a complex history of varying kinematic styles. Development of a migrating gap in the subducted plate (a "slab window") beneath the leading edge of North America (Figure 12) offers a mechanism for increased asthenospheric upwelling inboard of the triple junction as envisaged by Dickinson and Snyder [1979]. In addition, the dextral convergence of the Kula plate to the north of the triple junction could have imparted tractions beneath the Coast Ranges that would have tended to displace neartrench slivers northwestward, while the more orthogonal tractions of the Farallon plate to the south of the triple junction would have resulted in compression with little or no displacement. Thus the differential motions of the tectonic slivers may have resulted in a net rifting environment. Subsequent passage of the triple junction northward could have allowed the resumption of normal convergence and the initiation of Cascades arc volcanism after about $42 \mathrm{Ma}$.

\section{DISCUSSION}

Although the original form of the Crescent volcanics remains uncertain, there is no doubt that these basalts are comparable to the thickest extrusive sequences in the world. Furthermore, the $250,000 \mathrm{~km}^{3}$ or greater volume of the CRVP as a whole exceeds that of most continental rift zones and some flood basalt provinces. It is obvious from composition and lithology that the Crescent volcanics were not produced by the Andeantype subduction regime that apparently existed in the Pacific Northwest prior to $60 \mathrm{Ma}$. However, the Crescent basalts do show features that could be interpreted as the product of several different tectonic environments, including plume-influenced mid-oceanic ridges, hotspot related oceanic islands, and continental rift-related volcanics. To establish the origin of the Crescent Formation (and the CRVP in general), constraints related to age, lithology and stratigraphy, paleomagnetism and plate kinematics, and geochemistry must be considered.

\section{Age}

A symmetrical outward progression of available extrusive ages from younger in the center towards older on the north and south ends of the CRVP has been reported by Duncan [1982] and cited as evidence for an accreted seamount origin. However, the samples dated were not stratigraphically controlled, so the onset and cessation of extrusion have yet to be established. The Crescent volcanics (sensu stricto) have not been radiometrically dated, although presumably correlative flows from the Bremerton and Metchosin volcanics have ${ }^{40} \mathrm{Ar} /{ }^{39} \mathrm{Ar}$ ages of circa 55 and $57 \mathrm{Ma}$, respectively 
6814

BabCock et al.: RIfTEd MARgin ORIGIN fOR the CRESCENT Basalts
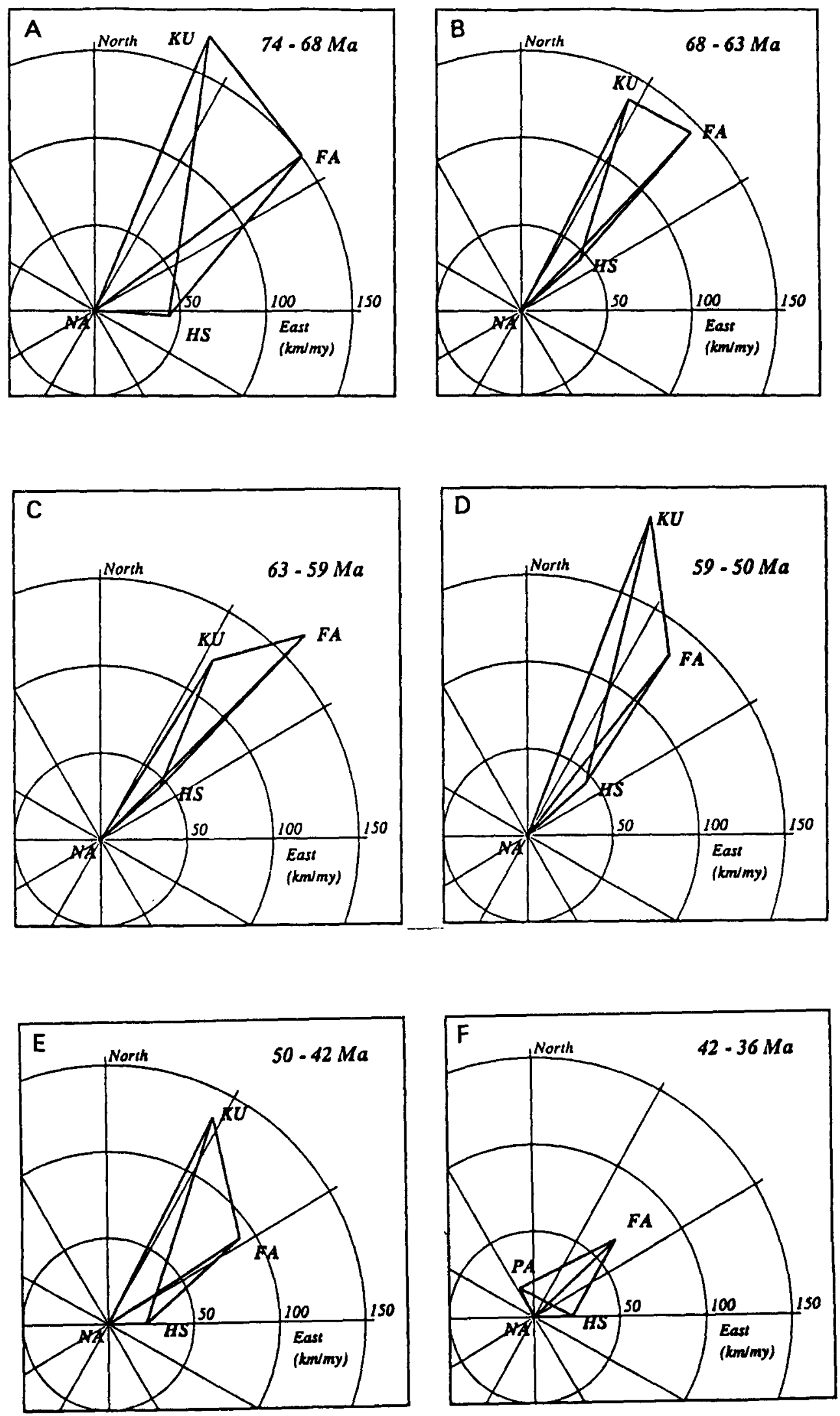

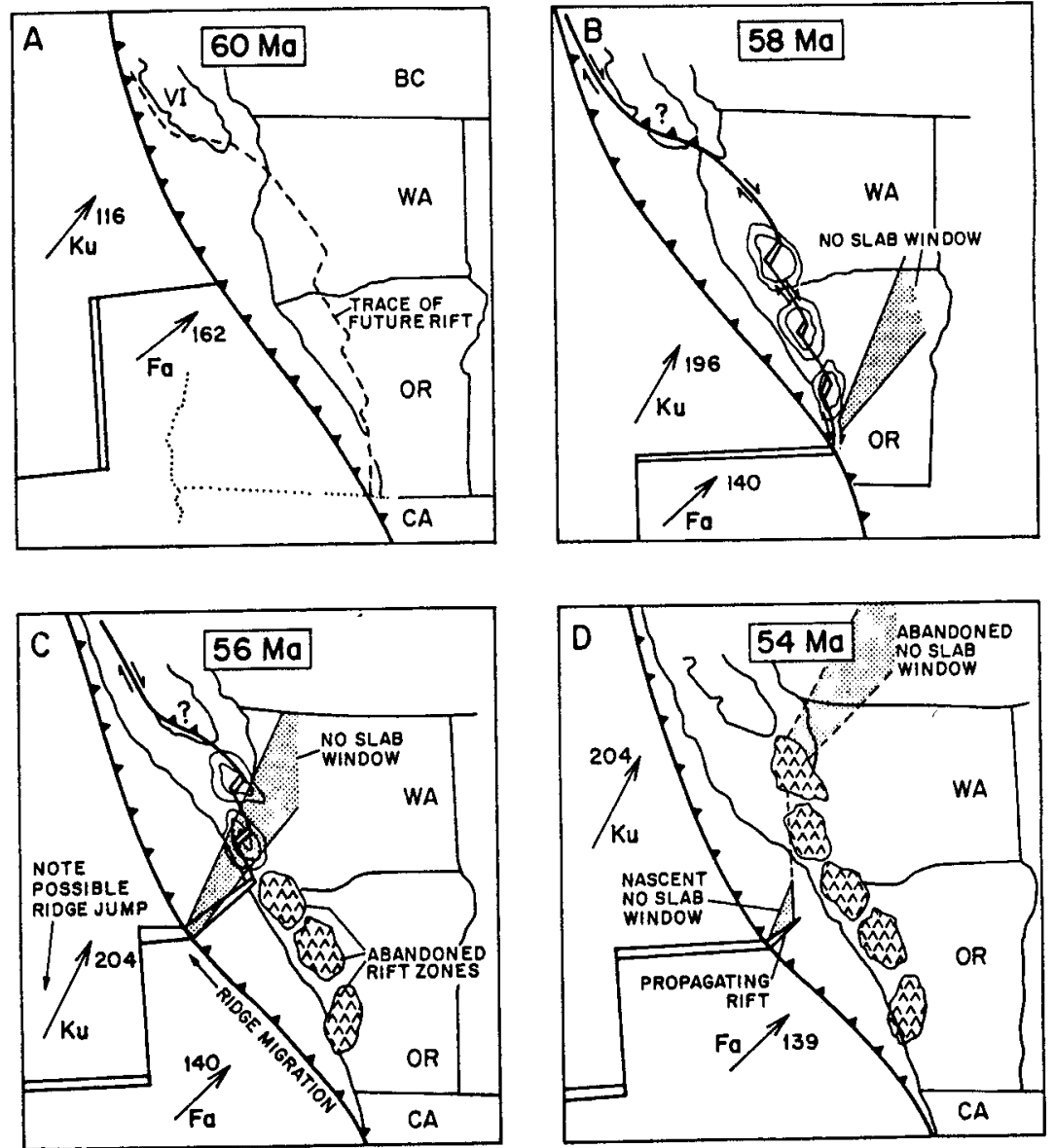

Fig. 12. Diagram showing a hypothetical continental margin rift system during early to middle Eocene. Emergent island extrusive centers shown in contoured patterns. Abbreviations are KU, Kula Plate; FA, Farallon Plate; and NA, North American plate. Very approximate location of a no-slab window is shown in stippled pattern. Note that complex patterns of slab geometry will develop as the triple junction migrates and transform faults are encountered. The position of extrusive centers and the geometry of spreading is shown schematically. VI is Vancouver Island.

[Duncan, 1982]. This narrow age range is extended considerably by the circa $50 \mathrm{Ma}{ }^{40} \mathrm{Ar} /{ }^{39} \mathrm{Ar}$ date for the Bremerton intrusive complex reported in this paper. The Ulatisian to lower Narizian age of the foraminiferal assemblage in the sediments interbedded with bona fide
Crescent flows at Pulali Point is even younger at circa $48 \mathrm{Ma}$. Extrusion of tholeiitic lavas over a period of 5-9 $m . y$. is far longer than would be expected for oceanic islands constructed on either the Farallon or Kula plates, which were moving rapidly relative to the

Fig. 11. Plate movement polygons constructed for a position near present-day Olympic Peninsula (latitude $48^{\circ}$ north; longitude, $236^{\circ}$ east). The graphs show linear velocities relative to a fixed North America. Abbreviations are KU, Kula Plate; FA, Farallon Plate; NA, North America; and HS, hotspots. To interpret the plots, follow a tie line from the origin (NA) outward to the apex representing the plate of interest. The direction of the relative movement is given in degrees east of the north axis and the velocity by the length of the tie line, with respect to the concentric circles in kilometers per million years. The motion relative to the hotspots is likewise indicated by the tie line from HS to the plate of interest. For example, during the interval 74-68 Ma, the Farallon plate was moving northeast with respect to North America with a relative velocity of $150 \mathrm{~km} / \mathrm{m}$.y., while North America almost due west at a velocity of about $45 \mathrm{~km} / \mathrm{m}$.y. The orientation of the KU-FA ridge would be perpendicular to the tie lie between these plates. Note the large changes in KU and FA relative motion and the orientation of the KU-FA ridge between 63 and $59 \mathrm{Ma}$. Also note the decrease in all relative plate velocities at about $42 \mathrm{Ma}$, coincident with the cessation of PA-KU spreading. 
position of the Yellowstone hotspot (calculated rates are 60 and $200 \mathrm{~km} / \mathrm{m}$.y. respectively). The $48-50 \mathrm{Ma}$ ages for the Crescent and adjacent Bremerton volcanics also disrupt the age symmetry of the CRVP, which was one of the bases for the seamount accretion hypothesis.

\section{Lithology and Stratigraphy}

Although tectonic repetition of the Crescent basalts cannot be precluded without a detailed structural study, the data available indicate that continuous extrusive sequences of as much as $7-8 \mathrm{~km}$ are present in the Crescent Formation. Elsewhere in the CRVP, the average thickness of volcanics is $3 \mathrm{~km}$, with eruptive centers in excess of $6 \mathrm{~km}$ and a total volume of 250,000 $\mathrm{km}^{3}$ [Snavely et al., 1968; Duncan, 1982]. Such volumes require anomalously high mantle potential temperatures generally associated with convective plumes [White et al., 1989]. The tholeitic submarine basalts that form the lower part of the Cresent sequence have been interpreted as normal oceanic crust [Glassley, 1974; Cady, 1975; Muller, 1980], but this seems implausible for two reasons (not counting the remarkable thickness). First, our mapping confirms the observation that the continentally derived turbidites of the underlying Blue Mountain unit are interfingered and interbedded with Crescent flows [Cady, 1975; Einarsen, 1987]. Also, interbeds of terriginous sediments are observed throughout the volcanic sequence. Thus it can be demonstrated that the Crescent basalts were extruded in a basin developed in close proximity to the margin of North America. A second problem with interpreting the Crescent sequence as normal oceanic crust, possibly thickened by folding or thrusting, is the lack of ophiolite lithologies. Despite extensive mapping, sheeted dikes and associated gabbros are known to occur at only two localities; ultramafic rocks have not been found except as rare cumulate layers in the basalts.

It also is difficult to reconcile the structures observed in the overlying marine sedimentary sequence with the seamount accretion hypothesis. At Pulali Point the sedimentary sequence is conformable and apparently interbedded with the Crescent flows. Late Eocene reverse faulting found in the northern part of the Olympic Peninsula occurred after deposition of the basal part of the sedimentary sequence according to Tabor [1987]. Nowhere is there evidence of the intense compressional or transpressional deformation that would have accompanied a major collision. In fact, detailed structural studies in the Bremerton area by Clark [1989] provide good evidence for synextrusive extension.

On the basis of the evidence cited above, we prefer the interpretation that the Crescent volcanics were extruded into a subsiding basin that was formed by rifting along the margin of North America. Emergent volcanic islands developed and coalesced in the vicinity of major volcanic centers where extrusion exceeded the rate of basin subsidence. The extremely thick section of pillow basalts found at the base of the Dosewallips sequence suggests that a massive melting event initiated extrusion. This may indicate the arrival of the diapiric "head" of a mantle plume [see Richards et al., 1989]. During the waning stages of volcanism, subsidence again became dominant, resulting in zones of pillow basalts in the uppermost Crescent Formation and finally continuous deposition of marine sediments, some of which are interbedded with the uppermost exposed flows at Pulali Point.

\section{Paleomagnetism and Tectonic Setting}

The paleomagnetic results of this study confirm previous work in the northern Olympic Peninsula by Engebretson et al. [1988] and Warnock [1989] indicating that the Crescent Formation has experienced little or no poleward displacement since extrusion. However, our results show no significant rotation involved. This contrasts with the clockwise rotations of coeval basalts in the more southerly part of the CRVP that are probably attributable to differential Basin and Range extension [Wells et al., 1984]. It is interesting to note that the apparent northern limit of clockwise rotation in the Olympic Mountains (the Bremerton Igneous Complex) is roughly coincident with the trend of the enigmatic Olympic-Wallowa lineament (OWL). The paleomagnetic data also show that the CRVP could not have been generated by accretion of a chain of oceanic seamounts unless there was fragmentation and complex rotation during accretion [cf. Wells et al., 1984]. Paleotectonic analysis by Einarsen [1987] shows that when the Crescent terrane is reconstructed as a seamount mass on either the Kula or Farallon plates at $58 \mathrm{Ma}$, the nearest great circle distance to the margin of North America is about $2000 \mathrm{~km}$. This is inconsistent with the presence of terriginous sediments of Cascades, San Juan Islands, and Coast Plutonic Complex provenance that underlie and are interbedded with the Crescent basalts.

It appears that the initiation of Crescent volcanism (and the CRVP in general) was likely related to plate kinematics during the early to middle Eocene. The most obvious relationship is that there was a distinct increase in both the velocity and obliquity of convergence of the Kula and Farallon plates with respect to North America that closely coincided with the onset of volcanism around $60 \mathrm{Ma}$ (Figure 11). Given that a spreading ridge and associated hot upwelling mantle material were located fairly nearshore, this change in plate interaction alone might have induced trans-tensional rifting as the ridge was subducted along the margin of North America. However, a more important factor may have been a remarkable shift in the orientation of the Kula-Farallon ridge. Plate kinematic modeling by Engebretson et al. 
[1985] or Stock and Molnar [1988] allows the ridge to have been almost anywhere in the geographic region from Northern California to Southeast Alaska during the early Eocene (Figure 10). If the triple junction was in fact in the vicinity of $48^{\circ} \mathrm{N}$, our calculations indicate that there would have been an abrupt change in the Kula-Farallon ridge from an azimuth of $345^{\circ}$ and convergence rate of $55 \mathrm{~km} / \mathrm{m}$.y. (63-59 Ma) to $82^{\circ}$ and $80 \mathrm{~km} / \mathrm{m} . \mathrm{y}$. (59-50 Ma). This would have shifted the orientation of the ridge nearly $90^{\circ}$ from nearly parallel to nearly perpendicular to the margin of North America (see Figure 12).

There are at least two ways in which triple junction interaction might have induced rifting along the continental margin. One is the $20^{\circ}$ difference in the convergence vectors of the Kula and Farallon plates between 59 and $50 \mathrm{Ma}$. Any mechanical linkage between the descending slabs and the overlying plate would have produced tension along the trace of the subducted ridge. The zone of tension and rifting would have migrated with the triple junction along the continental margin, with occasional jumps in position as ridge transforms were encountered. Another triple junction effect could have been development of slab gaps due to the cessation of magmatism as the ridge arrived at the subduction zone. Asthenospheric mantle upwelling into the widening gap could have induced rifting and basaltic magmatism [cf. Dickinson and Synder, 1979; Thorkelson and Taylor, 1989]. The pattern of magmatism would depend upon the number and orientation of transform offsets and the migration of the triple junction along the continental margin (see Figure 12). Strong support for a triple junction mechanism is provided by recent paleomagnetic results from the Resurrection Peninsula (Alaska) ophiolite, which is interpreted to be a remnant of the extinct Kula-Farallon ridge. The paleolatitude and paleostrike obtained from these rocks indicate that the ridge, trending NNE, intersected the continental margin somewhere near the Olympic Peninsula at $57 \mathrm{Ma}$ [Coe et al., 1990].

If the CRVP represents accreted seamounts, then the initiation of Cascades arc volcanism could be explained simply by the outward stepping of subduction after accretion [Leeman et al., 1990]. However, the Crescent-like Greys River volcanics are interbedded with the arc-like Northcraft volcanics, which have been reported to have an age of about $42 \mathrm{Ma}$ [Phillips et al., 1989]. This close association of contrasting types of volcanism is difficult to explain in terms of a collision model, but coexistence of different magma types would be expected during the transition from a rift to a subduction regime due to a change in plate kinematics. After extrusion of the Coast Range basalts, the KulaFarallon ridge would have migrated northward and been replaced by the Farallon-Pacific ridge. Our kinematic model estimates that the Farallon-Pacific ridge orientation would have changed back from about $80^{\circ}$ to $345^{\circ}$ after $42 \mathrm{Ma}$ (Figure $11 \mathrm{f}$ ). This corresponds in time to the transition from Crescent-like magmas in the Greys River volcanics to Cascades-arc volcanics of the Northcraft Formation [Phillips et al., 1989]. Thus it appears that both the initiation and demise of Crescenttype volcanism could have been triggered by triple junction migration or reorientation.

Analysis of oceanic plate motion indicates that the western margin of North America at $40^{\circ}-50^{\circ}$ north latitude should have been marked by subduction of varying obliquity for the past 90 m.y. From about 90 to $60 \mathrm{Ma}$ the Cascades Crystalline Core, located directly inboard of the Crescent Formation, experienced intrusion of voluminous granitic plutons. These have been attributed by Whitney and McGroder [1989] to melting during or just after the collision of Wrangellia. However, Miller et al. [1989] argue that the Cretaceous plutons correspond to a period of convergence and collision along the margin, followed by a short magmatic lull from 85 to $78 \mathrm{Ma}$. A northwest trending belt of plutons dated at 78-73 $\mathrm{Ma}$ were then intruded during a period of increased oblique convergence. Between 59 and $50 \mathrm{Ma}$ there is an apparent hiatus, indicating that subduction-related magmatism "switched off." This would be consistent with the occurrence of Crescent rifting in a fore-arc setting, with arc magmatism ceasing as extension began.

The enigmatic "Challis arc" spanning 62-48 $\mathrm{Ma}$ is largely coeval with Crescent volcanism. The broad areal distribution of Challis magmatism has been attributed to shallow subduction by Armstrong [1988]. However, the Colville Igneous Complex, emplaced directly inboard of the Crescent volcanics from 65 to 47 $\mathrm{Ma}$, is undoubtedly related to extension [Carlson and Moye, 1990; Holder et al., 1990]. Furthermore, geochemical studies by Norman and Leeman [1989] show that the type Challis magmas are probably related to processes other than subduction. Thus it seems probable that the entire region was undergoing extension during Crescent extrusion and that there was minimal magmatism directly related to subduction. Possible analogs to the CRVP include the Gulf of California and the Bransfield Straits, where arc volcanism "switched off" before rifting began [Saunders et al., 1987]. The stratigraphy and thickness of the Crescent volcanic sequence also is intriguingly similar to "volcanic passive margin" sequences, known primarily through seismic studies [Hinz, 1981].

The position of the Yellowstone hotspot (YHS) also is a possible factor in the generation of the CRVP. As previously discussed, the western margin of North America would have approached the geographic position of the Yellowstone hotspot (YHS) at about 60 Ma. Recent studies show that voluminous basaltic volcanism is associated with the development of hotspots, but there is no consensus whether rifting 
follows [e.g. Richards et al., 1989] or precedes [e.g., White and McKenzie, 1989] the initiation of extrusion. Any relationship between the YHS and the Crescent Formation is tenuous because existing plate tectonic reconstructions show the hotspot coming onshore far to the south, at the latitude of southern Oregon (Figure 10). However, it is estimated by White and McKenzie [1989] that hotspots affect an area as much as $2000 \mathrm{~km}$ in diameter, and latitude constraints of the plate modeling allow the center of the YHS to be as far north as the Olympic Mountains. Note that the CRVP should not be considered a "hotspot track," but a series of separate extrusive centers associated with mantle upwelling on a regional scale.

The relationship between magmatism and plate kinematics is a crucial problem. If it can be established that the Crescent (and the CRVP?) basalts were generated by the passage of the Kula-Farallon-North America triple junction, then a critical constraint can be established for plate reconstructions during the Eocene.

\section{Geochemistry}

The most distinctive feature of Crescent volcanism is the transition in chemistry from the lower Crescent type (LCT) to the upper Crescent type (UCT), which roughly corresponds to the change from submarine to subaerial flows in the Dosewallips reference sequence. At least some dikes in the LCT have a chemical affinity to the UCT flows (Table 3). None of these could be physically traced into the UCT, but if they are feeder dikes, then the entire Crescent sequence must have been extruded in situ rather than tectonically juxtaposed.

Source discrimination diagrams (e.g., Figure 7) show that the LCT flows resemble N-MORB to E-MORB basalts, while the UCT flows fall in the fields of EMORB to P-MORB or OIB types. Although the Crescent basalts shows a distinct enrichment of high field strength elements relative to MORB, they are less enriched than typical oceanic island tholeiites and display no evidence of the titanium and niobium depletions that characterize arc and initial back-arc magmas. Table 5 provides a comparison between the more "primitive" ( $\mathrm{Mg}$ number about 60 ) and comparable basalts from several known tectonic environments in the Pacific Northwest. These data show that the Crescent basalts are similar to (but not the same as) magmas generated along the Explorer Ridge spreading center. The change in composition from LCT to UCT has the same sense as the shift from ridge to seamount magmas, except that the UCT is consistently more enriched in $\mathrm{Nb}, \mathrm{Zr}$, and $\mathrm{Ce}$ than the seamounts. Note that the continental flood basalts of the Picture Gorge are distinctly different in composition. However, there is a similarity between the Crescent and arc-type (?) basalts of Mount Adams, which are interpreted by Leeman et al. [1990] to be due to variable partial melting of a heterogeneous OIB- to MORB-source domain.

Our preferred interpretation is that Crescent magmatism is the result of rifting associated with a mantle plume that impinged on the forearc of a late Mesozoic to early Tertiary subduction system. The data available cannot distinguish whether the plume was induced by rifting or vice versa. Prior to extrusion, it appears that any arc magmatism "switched off" due to an increase in the obliquity of subduction or the northward passage of the Kula-Farallon-North America triple junction. There are several ways in which the variably enriched chemistry of the Crescent basalts could be generated in this setting. One is progressive metasomatic enrichment of the lithospheric mantle above the subduction system that preceded Crescent extrusion. The LCT, produced during early stages of rifting, could have involved an upper mantle source that was less enriched than the lower mantle immediately above the subducting slab. The deeper enriched zone, however, would have upwelled and partially melted

TABLE 5. Comparison of "Primitive" (Mg Number > 60) Crescent Basalts From the Dosewallips Sequence With Other Basalts of Comparable Mg Number From Different Tectonic Settings in the Pacific Northwest

\begin{tabular}{llllllllll}
\hline & LC & UC & DS & CS & ER & PG & MA & EM & OIB \\
\hline $\mathrm{Zr} / \mathrm{Nb}$ & 11.7 & 9.2 & 18.8 & 13.2 & 12.1 & 23.9 & 13.5 & 8.8 & 5.8 \\
$\mathrm{La} / \mathrm{Nb}$ & 0.8 & 0.3 & 0.9 & 0.8 & 0.7 & 1.9 & 0.5 & 0.8 & 0.8 \\
$\mathrm{Y} / \mathrm{Nb}$ & 4.6 & 2.0 & 4.7 & 3.0 & $3.2 \checkmark$ & 7.3 & 3.0 & 2.7 & 0.6 \\
$\mathrm{Zr} / \mathrm{Y}$ & 2.6 & 4.6 & 4.0 & 4.5 & 3.8 & 3.3 & 4.4 & 3.3 & 9.7 \\
$\mathrm{Ce} / \mathrm{Y}$ & 0.9 & 1.2 & 0.6 & 0.7 & 0.6 & 0.6 & 0.4 & 0.7 & 2.8 \\
$\mathrm{Mg} *$ & 63 & 60 & 60 & 59 & 61 & 58 & 57 & - & -
\end{tabular}

Basalts are LC, average of five "primitive" lower Crescent basalts; UC, average of five "primitive" upper Crescent basalts; DS, Dellwood Seamount, analysis (4) [Cousens et al., 1984]; CS, Cobb Seamount, DH8-8 [Desonie and Duncan, 1990]; ER, Explorer Rift, analysis (6) [Cousens et al., 1984]; PG, Picture Gorge Basalt, BBJ-189 [Bailey, 1989]; MA, Mount Adams, 83-49 [Leeman et al., 1990]; EM, E-MORB [Sun and McDonough, 1989]; and OIB, oceanic island basalt [Sun and McDonough, 1989]. 
during the later stages of rifting to produce the UCT. Variable enrichment of the mantle source could also have been produced by the infiltration of very low percentage "steady state" melts from the deep mantle below the source zone [see McKenzie, 1989]. Another possibility is variable mixing of partial melts from at least two different sources, one relatively depleted (lithospheric mantle?) and another enriched (primitive mantle?).

The transition from Crescent-like to arc-like magmatism seems to be marked by the chemistry of late Eocene volcanics in southwest Washington. The Greys River volcanics are low alumina (about 12-14\%), Ti- and Nb-enriched basalts, while the closely associated Northcraft volcanics (42 Ma) show an abrupt change to high-alumina (about 16-17\%), low-Ti basalts and a considerably greater degree of differentiation that characterizes subsequent volcanic units of the Cascades arc (for data see Phillips et al., [1989]).

\section{CONCLUSIONS}

Our interpretation of the tectonic environment during the extrusion of the Crescent basalts is rifting in the forearc of a preexisting Andean-type subduction system. Rifting was probably triggered by a distinct increase in the velocity and obliquity of the convergence of the Kula plate with respect to North America at about $60 \mathrm{Ma}$. Concurrently, it appears that subduction "switched off" and was not a factor in magma production until the initiation of the Cascades arc at about $42 \mathrm{Ma}$. It is possible that the change in the sense of convergence alone produced a tran-sextenional rift environment and small-scale volcanism in parts of the CRVP. However, it seems likely that large extrusive centers, such as the Crescent, mark the position of the Kula-Farallon-North America triple junction during the Eocene. There are two ways by which the passage of the triple junction along the continental margin could have induced more extensive rifting and volcanism. One is differential traction on the overriding North American plate due to the variation (about $20^{\circ}$ ) in the convergence vectors of the Kula and Farallon plates. The other is the development of a slab window inboard of the subducted Kula-Farallon ridge. If mantle upwelling was localized by the slab gap, voluminous basalts could be generated by decompression melting. Crescent (and CRVP) volcanism also could be due to rifting caused by convective upwelling of the Yellowstone hotspot, which tectonic modeling puts in the vicinity of the continental margin of North America at about $60 \mathrm{Ma}$. Alternatively, the Yellowstone hotspot could have been initiated by slab fragmentation and rifting due to plate interactions during the early Eocene.

Extrusion of the Crescent basalts persisted for as much as 7-8 m.y. and involved two distinct magma types. In the Dosewallips reference section, an $8.4 \mathrm{~km}$ thick lower part of the sequence consists predominantly of pillowed submarine to massive flows that were derived from a relatively depleted source resembling $\mathrm{N}$ to E-MORB. The $7.8 \mathrm{~km}$ thick upper part of the sequence is composed of pillowed to massive subaerial flows derived from an enriched E-MORB to OIB source. It can be inferred that the lower Crescent Formation represents partial melting of depleted lithospheric mantle "streaked" with a metasomatic component from a preexisting subduction system or infiltrated by "steady state" partial melts from the upper mantle. The more enriched upper Crescent Formation could represent mixing of partial melts from upwelling primitive mantle driven by a convective plume or simply a more enriched zone of the same mantle source that produced the lower Crescent basalts.

If it can be demonstrated that the Crescent volcanics were indeed produced by rifting at the position of the Kula-Farallon-North America triple junction, then it will be possible to create far more precise models for oceanic plate evolution and sharpen tectonic interpretations elsewhere in the Cordillera. For example, a rift-regime in the Crescent Formation (CRVP), coupled with evidence for coeval extension associated with Challis magmatism, would clearly mark the end of Laramide compression in this part of the Cordillera.

To resolve uncertainties in the petrogenesis of the Crescent Formation, further structural and isotopic analyses are needed. More detailed studies of the relationship of the Crescent to other volcanic centers in the CRVP and their associated sedimentary basins also would be useful to more completely characterize the origin of this remarkable episode of volcanic activity.

Acknowledgements. The authors greatly appreciate the contributions of Sonia Bickel, who completed a stratigraphic and geochemical study in the critical transition zone between the upper and lower Crescent members as a senior thesis at the University of Puget Sound. Kevin Kelly, a graduate student at Western Washington University, was responsible for programming many of the tectonic reconstructions used in this study. Nick Massey provided an uncommonly thorough review, which eliminated some misconceptions and sharpened the focus of our arguments. Clark Blake, Ray Wells, and Tark Hamilton generated some important insights on CRVP evolution. Peter Hooper and Bob Duncan are to be thanked for providing $X$ ray fluorescence and ${ }^{40} \mathrm{Ar} /{ }^{39} \mathrm{Ar}$ analyses at minimum cost. This research was supported by grants from the Washington State Division of Geology and Earth Resources and the Bureau for Faculty Research at WWU.

\section{REFERENCES}

Armstrong, R.L., Mesozoic and early Cenozoic magmatic evolution of the Canadian Cordillera, Spec. Pap. Geol. Soc. Am. 218, 55-91, 1988.

Bailey, M.M., Revisions to stratigraphic nomenclature of the Picture Gorge Basalt Subgroup, Columbia River Basalt Group, in Volcanism and Tectonism in the Columbia River Flood-Basalt 
Province, edited by S.P. Reidel and P.R. Hooper, Spec. Pap. Geol. Soc. Am. 239, 67-84, 1989.

Beck, M.E., Jr. and D.C. Engebretson, Paleomagnetism of small basalt exposures in the West Puget Sound area, Washington, and speculations on the accretionary origin of the Olympic Mountains. J. Geophys. Res., 87, 3755-3760, 1982.

Brandon, M., and N.W.D. Massey, Early Tertiary tectonics of the Pacific Northwest: truncation and rifting with a transform plate boundary, in Symposium on the Deep Structure of Southern Vancouver Island, Results of LITHOPROBE Phase 1, Geol. Assoc. Can. Program Abst., 8, 9, 1985.

Byrne, T., Late Paleocene demise of the Kula-Pacific spreading center, Geology, 7, 341-344, 1979.

Cady, W.M., Tectonic setting of the Tertiary volcanic rocks of the Olympic Peninsula, Washington, J. Res. U.S. Geol. Surv., 3, 573582, 1975.

Carlson, D.H., and F.J. Moye, the Colville Igneous Complex; Paleogene volcanism, plutonism, and extension in northeastern Washington, Mem. Geol. Soc. Am., 174, 375-393, 1990.

Clark, K.P., Comparative stratigraphy, petrology, and geochemistry of the Crescent Formation and related exposures near Bremerton and Port Townsend, Washington, M.S. Thesis, 171 pp., West. Wash. Univ., Bellingham, 1989.

Coe, R.S., A.J. Bol, and C.S. Gromme, Early Eocene location and orientation of the Kula-Farallon Ridge: paleomagnetic results from the Resurrection Peninsula, Alaska (abstract), Eso Trans. AGU, 71, 1589, 1990.

Cousens, B.L., R.L. Chase, and J.G. Schilling, Basalt geochemistry of the Explorer Ridge area, northeast Pacific Ocean, Can. J. Earth Sci., 21, 157-170, 1984.

Desonie, D.L., and R.A. Duncan, The Cobb-Eickelberg seamount chain: Hotspot volcanism with mid-ocean ridge basalt affinity, $J$. Geophys. Res., 95, 12697-12711, 1990.

Dickinson, W.R, and W.S. Snyder, Geometry of subducted slabs related to San Andreas transform, J. Geol., 87, 609-627, 1979.

Diehl, J., M.E. Beck, Jr., S. Beske-Diehl, D. Jacobson, and C.B. Hearn, Jr., Paleomagnetism of the late Cretaceous-early Tertiary north central Montana alkalic province, J. Geophys. Res., 88, 10593-10610, 1983.

Duncan, R.A., A Captured island chain in the Coast Range of Oregon and Washington, J. Geophys. Res., 87, 10827-10837, 1982.

Einarsen, J.M., The petrography and tectonic significance of the Blue Mountain Unit, Olympic Peninsula, Washington, M.S. Thesis, 175 pp., West. Wash. Univ., Bellingham, 1987.

Engebretson, D.C., A. Cox, and R.G. Gordon, Relative motions between oceanic plates of the Pacific Basin, J. Geophys. Res., 89, 10291-10310, 1984.

Engebretson, D.C., R.G. Gordon, and A. Cox, Relative motions between oceanic and continental plates of the Pacific Basin, Spec. Pap, Geol. Soc. Am. 206, 59 pp., 1985.

Engebretson, D.C., A. Warnock, R. Burmester, K. Kelley, and M. Beck, Jr., Paleomagnetic results from the Crescent Formation on the Olympic Peninsula, Washington: a progress report (abstract), Eso Trans. $A G U, 69,1165,1988$.

Fisher, R.A., Dispersion on a sphere, Proc. R. Soc. London Ser. A., 217, 295-305, 1953.

Glassley, W.E., Geochemistry and tectonics of the Crescent volcanic rocks, Olympic Peninsula, Washington, Geol. Soc. Am. Bull., 93, 785-794, 1974.

Glassley, W.E., N.A. Lyttie, and D.B. Clarke, New analyses of Eocene basalt from the Olympic Peninsula, Washington: discussion and reply, Geol. Soc. Am Bull., 87, 1200-1204, 1976.

Heller, P.L., R.W. Tabor, and C.A. Suczek, Paleogeographic evolution of the United States Pacific Northwest during Paleogene time, Can. J. Earth Sci., 24, 1652-1667, 1987.

Hinz, K., A hypothesis on terrestrial catastrophes; wedges of very thick, oceanward-dipping layers beneath passive continental margins, Geol. Jahrb., Ser. E, 22, 3-28, 1981.

Holder, G.A.M., R.W. Holder, and D.H. Carlson, Middle Eocene dike swarms and their relation to contemporaneous plutonism, volcanism, core-complex mylonitization, and graben subsidence, Okanogan Highlands, Washington, Geology, 18, 1082-1085, 1990.

Kent, D.V., and F.M. Gradstein, A Cretaceous and Jurassic geochronology, Geol. Soc. Am. Bull., 96, 1419-1427, 1985.

Klitgord, K. and H. Schouten, Plate kinematics of the Central Atlantic, in The Geology of North America, vol. M, The Western North Atlantic Region, edited by P.R. Vogt and B.E. Tucholke, pp. 351-378, Geological Society of America, Boulder, Colo., 1986.

Leeman, W.P., D.R. Smith, W. Hjldreth, Z. Palacz, and N. Rogers, Compositional diversity of Late Cenozoic basalts in a transect across the Southern Washington Cascades: Implications for subduction zone magmatism, J. Geophys. Res., 95, 19561-19582, 1990.

LeRoex, A.P., H.J.B. Dick, A.J. Erlank, A.M. Reid, F.A. Frey, and S.R. Hart, Geochemistry, mineralogy and petrogenesis of lavas erupted along the southwest Indian ridge between the Bouvet triple junction and 11 degrees east, J. Petrol., 24, 267-318, 1983.

Lonsdale, P., Paleogene history of the Kula plate, Geol. Soc. Am. Bull., 100, 733-754, 1988.

Lyttle, N.A., and D.B. Clarke, New analyses of Eocene basalt from the Olympic Peninsula, Washington, Geol. Soc. Am. Bull., 86, 421427, 1975.

MacLeod, N.S., T.L. Tiffin, P.D. Snavely, and R.G. Currie, Geologic interpretation of magnetic and gravity anomalies in the Strait of Juan de Fuca, U.S.-Canada, Can J. Earth Sci., 14, 223-238, 1977.

Massey, N.W.D., Metchosin Igneous Complex, southern Vancouver Island: ophiolite stratigraphy developed in an emergent island setting, Geology, 7, 602-605, 1986.

McElhinny, M.W., Statistical significance of the fold test in paleomagnetism, Geophys. J.R. Astron. Soc., 8, 338-340, 1964.

McFadden, P.L., and M.W. McElhinny, A phsyical model for paleosecular variation, Geophys. J.R. Astron. Soc., 78, 809-830, 1984.

McKenzie, D., Some remarks on the movements of small melt fractions in the mantle, Earth Planet Sci. Lett., 95, 53-72, 1989.

Miller, R.B., S.A. Bowring, and W.J. Hoppe, Paleocene plutonism and its tectonic implications, North Cascades, Washington, Geology, 17, 846-849, 1989.

Muller, J.E., Chemistry and origin of the Eocene Metchosin volcanics, Vancouver Island, British Columbia, Can J. Earth Sci., 17, 199$209,1980$.

Norman, M.D., and W.P. Leeman, Geochemical evolution of Cenozoic-Cretaceous magmatism and its relation to tectonic setting, southwestern Idaho, U.S.A., Earth Planet. Sci. Lett., 94, 7896, 1989. 
Pearce, J.A., S.J. Lippard, and S. Roberts, in Marginal Basin Geology, edited by B.P. Kokelaar and M.F. Howells, Geo. Soc. Spec. Pub. 16, 77-943, 1984.

Phillips, W.M., T.J. Walsh, and R.A. Hagen, Eocene transition from oceanic to arc volcanism, southwest Washington, in Geological Geophysical and Tectonic Setting of the Cascade Range, U.S. Geol. Surv. Open File Rep., 89-178, 1989.

Richards, M.A., R.A. Duncan, and V.E. Courtillot, Flood basalts and hotspot tracks: plume heads and tails, Science, 246, 103-107, 1989.

Roberts, T.L., Gravity investigation of crustal structure in the Eastern' Olympic Peninsula-Puget Lowland area, Washington, M.S. Thesis, 105 pp., West. Wash. Univ., Bellingham, 1991.

Saunders, A.D., G. Rogers, G.G. Marriner, D.J. Terrell, and S.P. Verma, Geochemistry of Cenozoic volcanic rocks, Baja California, Mexico: implications for the petrogenesis of post-subduction magmas, J. Volcanology. Geotherm. Res., 32, 223-245, 1987.

Snavely, P.D. Jr., N.S. MacLeod, and H.C. Wagner, Tholeiitic and alkalic basalts of the Eocene Siletz River volcanics, Oregon Coast Range, Am J. Sci., 266, 454-481, 1968.

Stock, J., and P. Molnar, Uncertainties and implications of the Late Cretaceous and Tertiary position of the North America relative to the Farallon, Kula, and Pacific plates, Tectonics, 7, 1339-1384, 1988.

Sun, S.S., and W.F. McDonough, Chemical and isotopic systematics of oceanic basalts: implications for mantle composition and processes, in Magmatism in the Ocean Basins, edited by A.D. Saunders and M.J. Norry, Geol. Soc. Spec. Pub. London, 42, 313345, 1989.

Tabor, R.W., A Tertiary accreted terrane: oceanic basalt and sedimentary rocks in the Olympic Mountains, Washington
Centennial Field Guide--Cordilleran Sec., Geological Society of America, Boulder, Colo., pp. 377-382, 1987.

Tabor, R.W., and W:M. Cady, Geologic map of the Olympic Peninsula, Washington, U.S. Geol. Sur., Misc. Inv. Ser. Map I 994, 1978.

Thorkelson, D.J. and R.P. Taylor, Cordilleran slab windows, Geology, 17, 833-836, 1989.

Warnock, A.C., Paleomagnetism of the Crescent Formation on the Olympic Peninsula, Washington, Senior Thesis, 30 pp., Whitman College, Walla Walla, Washington, 1989.

Wells, R.E., D.C. Engebretson, P.D. Snavely, and R.S. Coe, Cenozoic plate motions and the volcano-tectonic evolution of western Oregon and Washington, Tectonics, 3, 274-294, 1984.

White, R., and D. McKenzie, Magmatism at rift zones: The generation of volcanic continental margins and flood basalts, $J$. Geophys. Res., 94, 8, 7685-7729, 1989.

Whitney, D.L., and M.F. McGroder, Cretaceous crustal section through the proposed Insular-Intermontane suture, North Cascades, Washington, Geology, 17, 555-558, 1989.

R.S. Babcock, R.F. Burmester, D.C. Engebretson, and A.C. Warnock. Department of Geology, Western Washington University, Bellingham, Washington 98225.

K.P. Clark, Department of Geology, University of Puget Sound, Tacoma, Washington 98416.

(Received April 9, 1991;

revised October 23, 1991;

accepted November 20,1991.) 